\title{
Mithraism under the microscope: new revelations about rituals through micromorphology, histotaphonomy and zooarchaeology
}

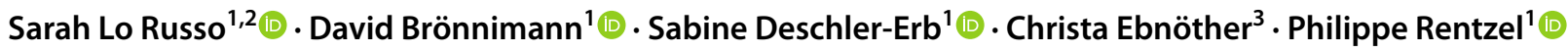

Received: 27 January 2021 / Accepted: 3 January 2022 / Published online: 19 February 2022

(c) The Author(s) 2022

\begin{abstract}
This paper is the first to use an innovative multi-proxy approach to obtain insights into hitherto unknown Mithraic cult practices. Using soil micromorphology, zooarchaeology and histotaphonomy, we investigated two mithraea (Biesheim FR, Kempraten $\mathrm{CH}$ ) and one cult cave (Zillis $\mathrm{CH}$ ). This was also the first study to include micromorphological and histotaphonomic approaches within the context of Mithraic research. The systematic evaluation of thermal alteration and bioerosion (in particular bacterial attack) on the animal bones, in combination with zooarchaeological results, allows a differentiation between various (cult) practices involving animals. Thanks to the micromorphological investigations, it was possible to demonstrate that repeatedly spreading combustion residues and renewing the floor were important parts of the cult practices of Mithraism. Our results suggest that a cult practice consisting of several stages was carried out on all three sites. Our study highlights that multiple floor constructions as well as the related sediments and (micro-) artefacts of cultic indoor features are important sources of information.
\end{abstract}

Keywords Roman Mithraism $\cdot$ Micromorphology $\cdot$ Histotaphonomy $\cdot$ Zooarchaeology $\cdot$ Mithraeum $\cdot$ Cult cave

\section{Introduction}

The Roman Mithras is a deity of oriental origin who was worshipped within closed communities and in special cult buildings (mithraea) throughout the Roman Empire since the first century AD. The cult of Mithras was one - the most successful - of the so-called mystery cults, since it was only open to those who had been introduced to the secret of the cult in question through specific initiation rituals, which, moreover, were subject to a ban on silence (Alvar 2008). This is one of the reasons why there are very few written sources; apart from iconographical evidence, it is mainly archaeological sources that can provide us with information about the cult and the rituals (Clauss 2001).

Sarah Lo Russo

sarah.lorusso@unibas.ch

1 Department of Environmental Science, Integrative Prehistory and Archaeological Science (IPAS), University of Basel, Basel, Switzerland

2 Department of History, Archeology, Arts, Philosophy and Ethics, Vrije Universiteit Brussel, Brussel, Belgium

3 Department of Archaeological Sciences, University of Bern, Bern, Switzerland
Mithraism still captivates the imagination of countless scholars. Various interdisciplinary analyses conducted by a plethora of archaeologists, religious studies scholars, epigraphists, numismatists, bioarchaeologists and other scholars have provided insight into the Mithraic community (Martens and Boe 2004; Mastrocinque 2017; McCarty and Egri 2020; Nagel et al. 2017). However, even the most recent research projects have largely ignored one important source: sediments.

This lack is all the more surprising because in Mithraism, unlike most other Roman religions, the cult was not practised in front of the temples, but rather inside cult buildings (mithraea or caves). Mithraea were usually dug into the ground and consisted of a three-naved cult room (spelaeum). A central aisle formed the central piece of this cult room. It was flanked on either side by raised podia (Hensen 2017). Archaeological layers within the remains of such buildings or caves are better protected from weathering and erosion than the antique surfaces outside the temples of other sacred sites (Koch et al., 2018). Because of this, mithraea and cult caves are especially useful for interdisciplinary analyses of sediments and micro-artefacts. Archaeological layers can be analysed micromorphologically in order to reconstruct formation processes and (ritual) activities. This has proven to 
be extremely fruitful in various contexts and has been used to research some antique cults (Devos and Paridaens 2019; Koch et al. 2018; Mentzer et al. 2015; Schucany et al. 2011). Yet, it has hardly been applied to the study of Mithraism. Our micromorphological analyses not only revealed archaeological layers as valuable sources for the reconstruction of ritual acts; they also, for the first time, enabled histotaphonomic investigations of the bones frequently found in thin sections. Ever since it first gained popularity in the 1980s, histotaphonomy has led to many interesting insights into the post-mortem processes of animals and humans (Bell 1995, 2012; Booth 2014; Brönnimann et al. 2018; Hackett 1981; Jans 2008; Turner-Walker and Jans 2008). Despite all of this, histotaphonomic approaches have never been used to better understand the Mithras cult.

This study endeavours to fulfil the following aims using the case studies of the cult cave of Zillis (Switzerland) and the Mithraea of Biesheim (France) and Kempraten (Switzerland) (Fig. 1):

- to identify activities based on burnt and un-burnt animal bones using macroscopic (zooarchaeology) and microscopic (histotaphonomy) methods;

- to reconstruct the formation processes indicative of repeated (cult) activities;

- to determine the commonalities and differences between the three investigated sites; and

- to evaluate the potential of combining micromorphology, histotaphonomy and zooarchaeology

\section{The Mithraeum of Biesheim}

The Roman settlement of Argentovaria covers approximately 200 ha and lies at an important Rhine crossing in the Alsace (near the communes of Biesheim and Kunheim, FR). This crossing was at times controlled by the Roman military (Reddé 2011). The mithraeum is located on the outskirts of the Roman settlement, which was a civilian settlement during the period the cult building was in use (second to fourth century AD) (Fortuné 2011). Although the mithraeum was investigated repeatedly between 1974 and 2002, it has not yet been excavated completely (Fortuné 2011; Kern 1991; Pétry 1976). The cult building is approximately $17 \mathrm{~m}$ in length and $6.5 \mathrm{~m}$ in width. It is divided into a three-aisled cult room (spelaeum) and two antechambers (apparatorium and pronaos) (Fig. 2). The typical ground plan as well as fragments of a tauroctony - the Mithraic cult relief - attest that the archaeological feature was a mithraeum (Kern 1991). During the most recent excavations, several superimposed loam floors and occupation layers containing charcoal were discovered in the central aisle (Fig. 3). These layers were sampled for micromorphological analysis and described succinctly in the publication of these research excavations (Rentzel 2011). Some 300 additional animal bones, mostly cattle bones, were preserved and recovered during excavation. However, as their exact find spots are unknown, it would not have been possible to carry out a thorough zooarchaeological analysis
Fig. 1 Mithras sanctuaries and pieces of evidence for the presence of the Mithras cult in the area under observation. The investigated sites are underlined (after Lo Russo et al. 2018)

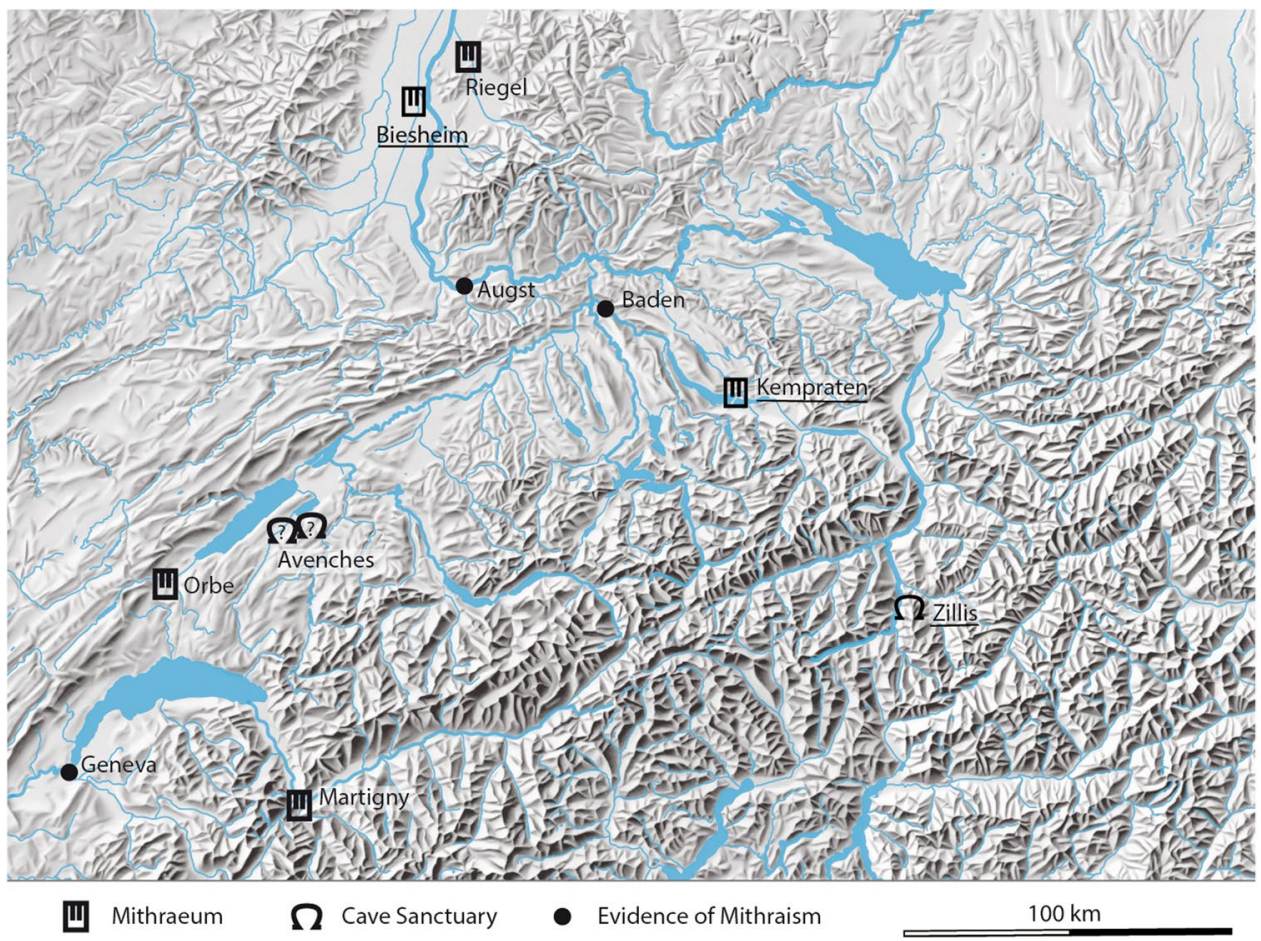


Fig. 2 a The cult cave of Zillis after the archaeological excavations (photo by S. Lo Russo) b Layout of the cult cave of Zillis. $\mathbf{c}$ Layout of the Mithraeum of Biesheim and location of the analysed profile in the middle aisle $\mathbf{d}$ Layout of the Mithraeum of Kempraten (phase 2). The rows of stones in the central aisle are part of the floor construction (after Fortuné 2011, Ebnöther et al. 2021 and Lo Russo et al. 2018)
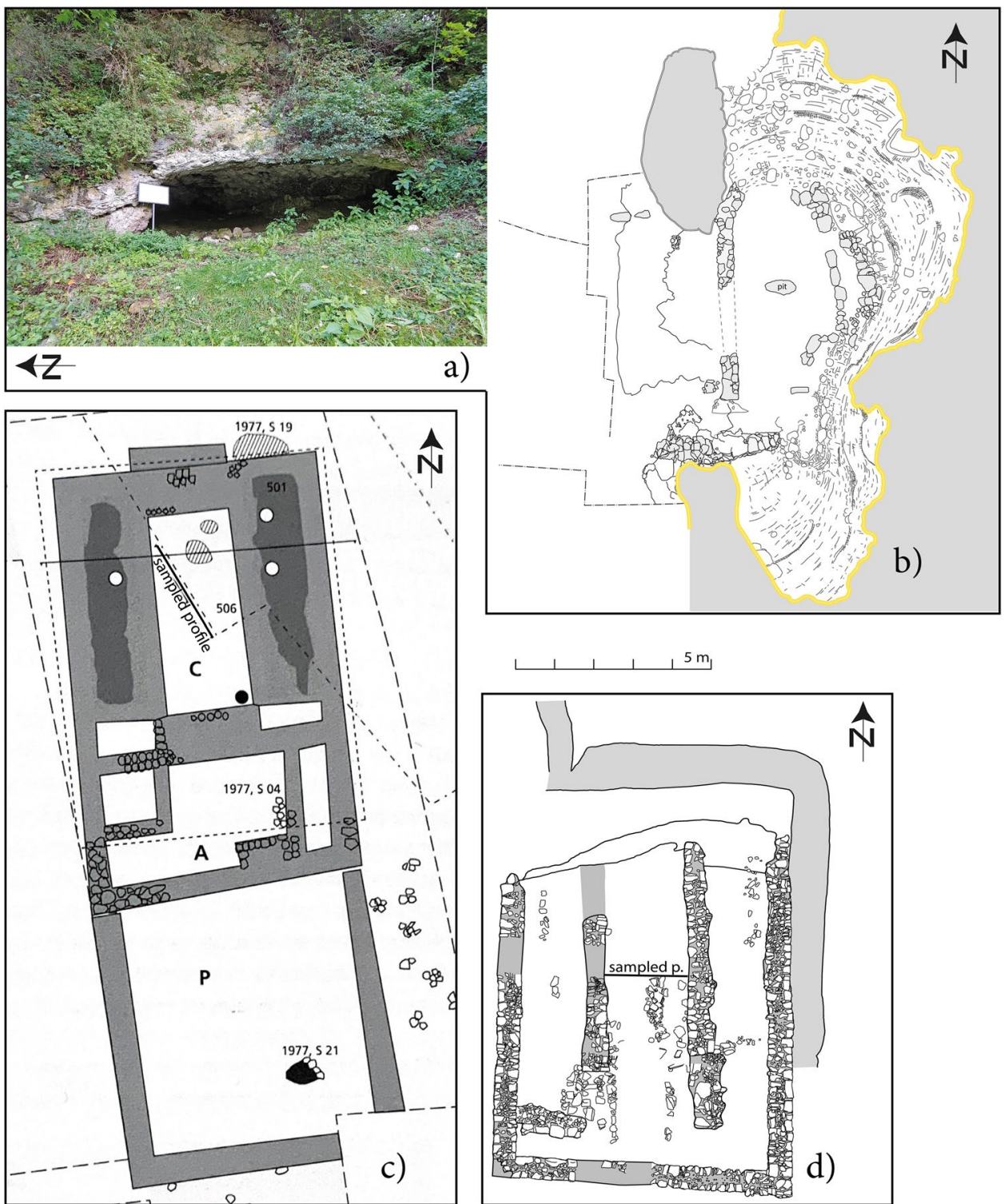

of these finds (Fortuné 2011). It was therefore decided to omit these bones from this study.

\section{The Late Roman cult cave in Zillis-Reischen}

The cave in Zillis-Reischen, Canton of Grisons $(\mathrm{CH})$, is situated in the Hinterrhein valley on the transalpine route leading through the Via Mala over the Alpine mountain passes of Splügen and San Bernardino to the South (Fig. 1). The cave is located on a terrace approximately $20 \mathrm{~m}$ above the Hinterrhein in the near vicinity of two late antique sites (Fig. 2). Excavations took place at the site in 1991/1992 and 1994/1995 (Liver and Rageth 2001; Rageth 1994). The cave has an inner floor surface of about $18 \mathrm{~m} 2$ and its mouth was closed off by a wall (Fig. 2). A large number of votive offerings, including approximately 650 coins dating between the third and early fifth century AD, ritual snake vessel, banqueting tableware and more than 13,000 unburnt animal bones were unearthed in areas both inside and just outside of the cave. The place itself, being a closed cave, with these kinds of finds, indicates that it was a place of cult activity. Whether Mithras was worshipped here or another oriental or orientalising deity cannot be conclusively assessed due to a lack of corresponding iconographic or epigraphic evidence. Nevertheless, the similarities with Mithraic cult rooms and find assemblages (including animal bones) are very striking - although this could also be due to the fact that assembly rooms of other cult associations are far less frequently recovered (Ebnöther et al. 2021).

As part of an interdisciplinary re-investigation of the features and finds, four micromorphological samples of the approximately $30-\mathrm{cm}$ thick, multi-layered occupation 


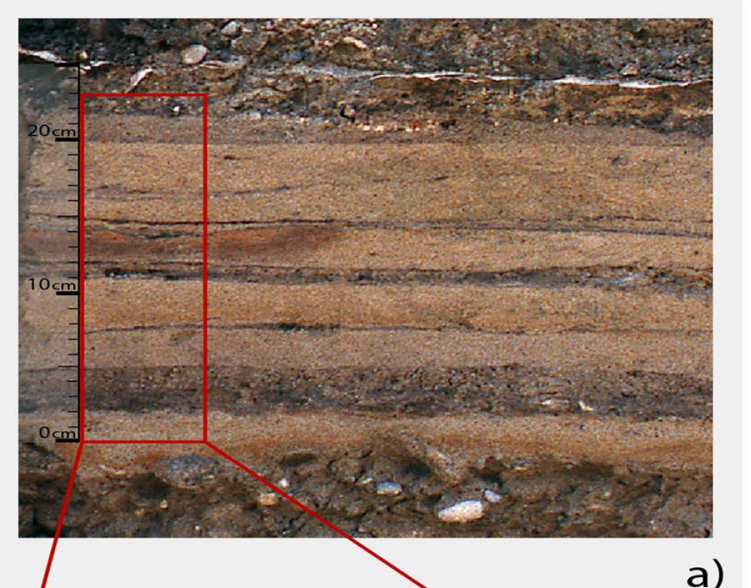

a)

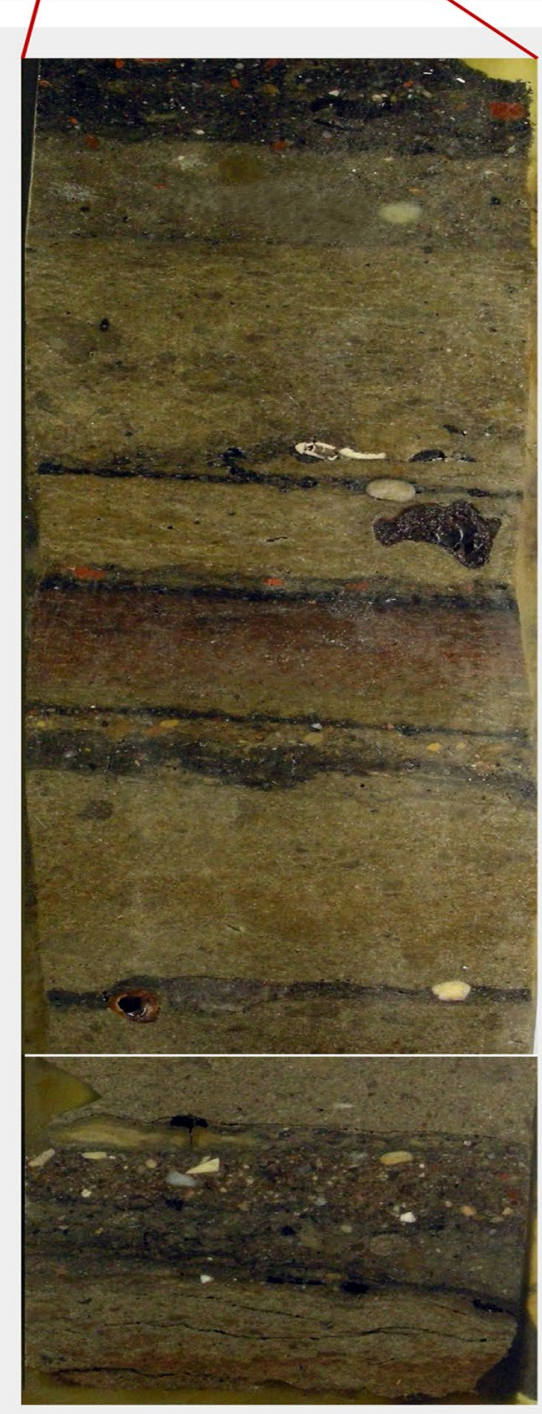

BIES 7

BIES 1

BIES 6

BIES 1

BIES 3

BIES 2

BIES 6

BIES 3

BIES 5

BIES 2

BIES 1

BIES 6

BIES 1

BIES 6

BIES 1

BIES 3

BIES 6

BIES 2

BIES 1

BIES 4

BIES 2

BIES 1

Fig. 3 a Photograph of the analysed profile in the middle aisle in the Mithraeum of Biesheim. b Photographs of the two analysed sections (cut faces of the resin-indurated blocks) from the middle aisle of

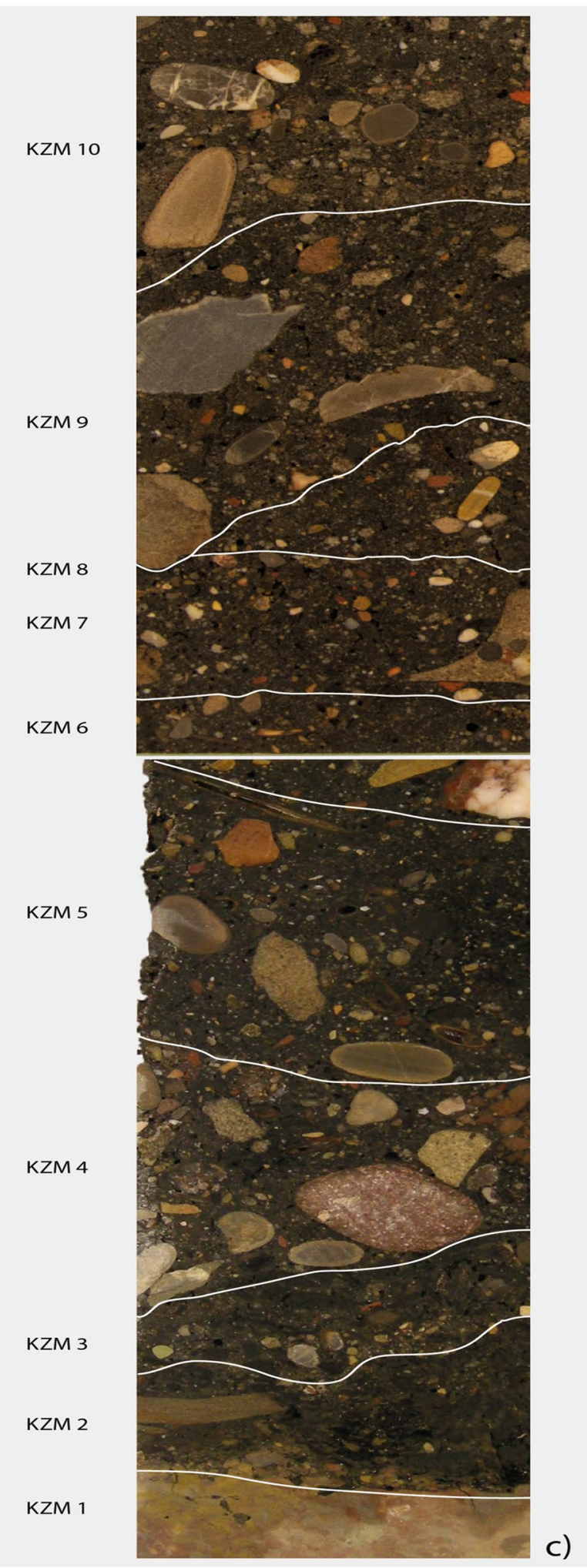

the Mithraeum of Biesheim and location of the microfacies. $\mathbf{c}$ Photographs of the two analysed sections from the middle aisle of the Mithraeum of Kempraten and location of the microfacies 


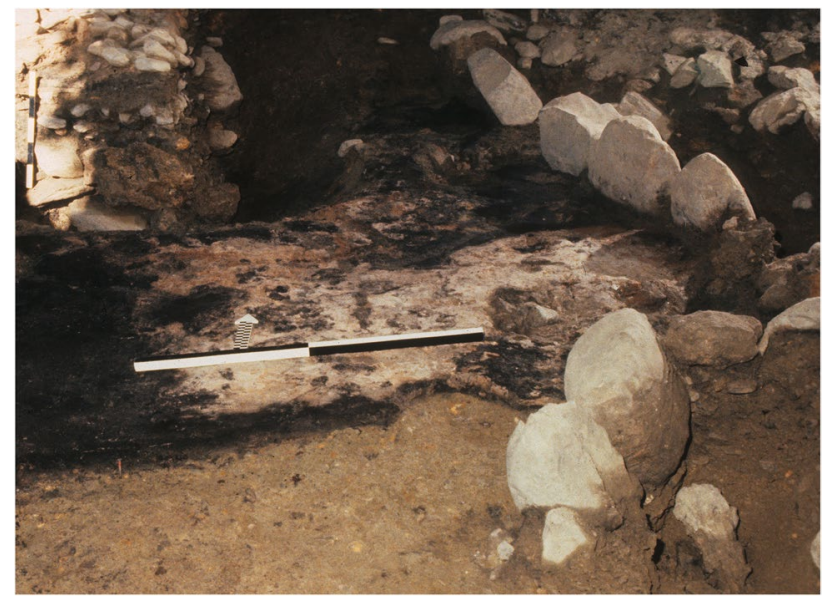

Fig. 4 Approximately 30-cm thick, multi-layered occupation layer from the interior of the cult cave of Zillis (after Ebnöther et al. 2021). For a better visibility of the fine layers see thin section scan (Fig. 9)

layer from the interior of the cave were analysed (Fig. 4). The exceptionally good preservation of these sediments in Zillis allowed us to identify similar but less well-preserved deposits in the mithraea of Biesheim and Kempraten, and to fully recognise parallels in rituals between all three (mithraic) sites. Therefore, Zillis is a key site for recognising rituals in sediments from within assembly rooms of mystery cults and may assist us with identifying the Mithras cult in particular, bearing in mind the slight doubts over its interpretation.

\section{The Mithraeum of Kempraten}

In Roman times, there was a civil settlement, which covered more than 11 ha, where Kempraten (RapperswilJona, $\mathrm{CH}$ ) lies today. The site is located right at Lake Zurich and would therefore have been a place of transfer between water- and overland ways (Ackermann 2013). The cult building was discovered during rescue excavations in 2015/2016. The mithraeum $(8 \times 10 \mathrm{~m})$ was situated just outside the settlement and was built at the latest at the end of the third century AD (Fig. 2). Three different construction phases could be detected (Lo Russo et al. 2018). As a partial assessment, a first evaluation of the archaeological features, a micromorphological analysis of the stratigraphical sequence from the central aisle (Fig. 3) as well as a small-scale, archaeobiological analyses were carried out with further assessments still ongoing (Ackermann et al. 2020; Häberle et al. 2021; Lo Russo 2021b; Lo Russo et al. 2018).

\section{Material and methods}

\section{Material}

For the Mithraea of Biesheim and Kempraten, one section containing the entire stratigraphical sequence of each of the mithraea's central aisle was geoarchaeologically sampled (Table 1). In Biesheim, two block samples were taken and studied micromorphologically (Rentzel 2011). In Kempraten, three block samples and several sediment samples from all three construction phases were analysed (Lo Russo 2021b). For this study, the results of the two best-preserved samples from Kempraten (Phase 1 and Phase 2) were considered. From the lower part of the charcoal-rich layer from the pagan cult cave of Zillis, three micromorphological samples, one sediment sample and finds collected by hand were studied (Lo Russo 2021a). The sediment sample was sieved, and animal bones (1-2 mm, 2-5 $\mathrm{mm}$ and 5-10 $\mathrm{mm}$ fractions) were targeted and analysed macroscopically for any burn marks (Table 1).

\section{Methods}

The block samples were taken from the profiles and layers using plaster bandages or plastic containers. They were impregnated with epoxy resin (Laromin C260, Araldite DY 026 SP, Aceton) and cut into several sections. The covered thin Sects. (30- $\mu \mathrm{m}$ thickness) were fabricated in Braunschweig (DE) and Basel (CH). An optical microscope (Leica DM-RXP) at a 16-630 magnification with a polarisation filter and UV light was used for the micromorphological analysis.

The layers were analysed regarding their grain size, structure, porosity, calcium carbonate content and composition in accordance with the guidelines for the micromorphological examination of archaeological sediments (Goldberg and
Table 1 Compilation of the involved disciplines and the analysed samples per site

\begin{tabular}{llll}
\hline Site & Biesheim & Zillis & Kempraten \\
\hline Disciplines & $\begin{array}{c}\text { Histotaphon- } \\
\text { omy, micro- } \\
\text { morphology }\end{array}$ & $\begin{array}{c}\text { Archaeology, zooarchaeol- } \\
\text { ogy, histotaphonomy, } \\
\text { micromorphology }\end{array}$ & histotaphonomy, micromorphology \\
Type of sample & $\begin{array}{c}\text { Block samples } \\
\text { from the } \\
\text { profile }\end{array}$ & $\begin{array}{c}\text { Animal bones, sediments } \\
\text { and block samples from the } \\
\text { layer inside the cave }\end{array}$ & Block samples from the profile \\
& & &
\end{tabular}


Macphail 2006; Stoops 2003). The natural (e.g. gastropod shells) and anthropogenic (micro-) components (e.g. charcoal, bone splinters, ash) were recorded using a 5-part semiquantitative scale (absent - few — common — frequent — dominant). The same was done for structural phenomena (compaction, horizontal orientation), indicators of bioturbation (e.g. earthworm granules) and post-sedimentary processes (e.g. dusty coatings, phosphate precipitations). Bone splinters (0.5-2 mm) and fragments ( $>2 \mathrm{~mm}$ ) were not only assessed semiquantitatively, we also established the number of bone splinters and fragments per square centimetre for the different layers in the thin sections. This makes it possible to determine and compare the density of bones of the individual microfacies. In addition, qualitative criteria, in particular the level of preservation, were also noted. Close attention was paid to taphonomic alterations in bone fragments and splinters embedded in soil samples. Within the scope of the histotaphonomic analyses, each bone fragment and splinter was assessed with regard to bioerosion (fungal and bacterial attack). For this a 6-part scale, the so-called BAI and WTI Index, was used (Table 2; $0=$ no bacterial or fungal attack and $5=$ the microstructure has been completely destroyed by bacterial or fungal attack). The fire overprint of the bones was similarly evaluated using a 7-part scale using the so-called HEI Index (Table 3, $0=$ unburnt and 3 =calcinated). For the evaluation of the thermal alteration (HEI), various criteria such as discolouration, collagen content, preservation of the microstructure and recrystallisations were used (Table 3) (Brönnimann et al. 2018). The assessment was in part based on the categorisation used by Squires et al. (2011) to classify cremated human bones. The animal bones taken from the oversized sieving material from Zillis were analysed for discolouration, a sign of heat exposure, using a microscope.

Table 2 Table with the Bacterial Attack Index (BAI) and the Wedl Tunnel Index (WTI)

\begin{tabular}{|c|c|c|c|c|}
\hline HEI & Colouring & Bone microstructure & Mineral microstructure & Description \\
\hline 0 & - & $\begin{array}{l}\text { No change in microstructure }(100 \% \\
\text { preserved) }\end{array}$ & Collagen fibres well visible & No thermal alteration \\
\hline 0.5 & Weak, orange-brown & $\begin{array}{l}\text { No change in microstructure }(100 \% \\
\text { preserved) }\end{array}$ & Collagen fibres well visible & $\begin{array}{l}\text { Presence of thermal alteration } \\
\text { possible (uncertain) }\end{array}$ \\
\hline 1 & Weak, orange-brown & $\begin{array}{l}\text { Minor changes in microstructure }(80 \% \\
\text { preserved) }\end{array}$ & $\begin{array}{l}\text { Collagen fibres visible; longitudinal } \\
\text { microfractures }\end{array}$ & Weak thermal alteration \\
\hline 1.5 & Distinct, orange-brown & $\begin{array}{l}\text { Minor changes in microstructure }(80 \% \\
\text { preserved) }\end{array}$ & $\begin{array}{l}\text { Collagen fibres still visible; longitudi- } \\
\text { nal microfractures, first formation of } \\
\text { crystalline structures }\end{array}$ & Moderate thermal alteration \\
\hline 2 & Distinct, brown & $\begin{array}{l}\text { Partly destroyed microstructure }(<50 \% \\
\text { preserved) }\end{array}$ & $\begin{array}{l}\text { Formation of large (cubic) crystalline } \\
\text { structures }\end{array}$ & Distinct thermal alteration \\
\hline 2.5 & Distinct, brown-grey & $\begin{array}{l}\text { Mostly destroyed microstructure (only } \\
\text { Haversian canals visible; }<20 \% \\
\text { preserved) }\end{array}$ & $\begin{array}{l}\text { Formation of large (cubic) crystalline } \\
\text { structures }\end{array}$ & Distinct thermal alteration \\
\hline 3 & Distinct, brown-grey & $\begin{array}{l}\text { Microstructure destroyed ( } 0 \% \text { pre- } \\
\text { served) }\end{array}$ & $\begin{array}{l}\text { The granular structure has completely } \\
\text { disappeared }\end{array}$ & Very distinct thermal alteration \\
\hline
\end{tabular}

Table 3 Table with the Heat Index (HEI)

\begin{tabular}{|c|c|c|c|c|}
\hline HEI & Colouring & Bone microstructure & Mineral structure & Description \\
\hline 0 & - & $\begin{array}{l}\text { No change in microstructure }(100 \% \\
\text { preserved) }\end{array}$ & Collagen fibres well visible & No thermal alteration \\
\hline 0.5 & Weak, orange-brown & $\begin{array}{l}\text { No change in microstructure }(100 \% \\
\text { preserved) }\end{array}$ & Collagen fibres well visible & $\begin{array}{l}\text { Probable thermal alteration } \\
\text { (uncertain) }\end{array}$ \\
\hline 1 & Weak, orange-brown & $\begin{array}{l}\text { Minor changes in microstructure } \\
\text { (>80\% preserved) }\end{array}$ & $\begin{array}{l}\text { Collagen fibres visible; longitudinal } \\
\text { microfractures }\end{array}$ & Weak thermal alteration \\
\hline 1.5 & Distinct, orange-brown & $\begin{array}{l}\text { Minor changes in microstructure } \\
\quad(>80 \% \text { preserved })\end{array}$ & $\begin{array}{l}\text { Collagen fibres still visible; longitu- } \\
\text { dinal microfractures; first forma- } \\
\text { tion of crystalline structures }\end{array}$ & Moderate thermal alteration \\
\hline 2 & Distinct, brown & $\begin{array}{l}\text { Partly destroyed microstructure } \\
(<50 \% \text { preserved })\end{array}$ & $\begin{array}{l}\text { Formation of large (cubic) crystal- } \\
\text { line structures }\end{array}$ & Distinct thermal alteration \\
\hline 2.5 & Strong, brown-grey & $\begin{array}{l}\text { Mostly destroyed microstructure } \\
\text { (only Haversian canals vis- } \\
\text { ible; }<20 \% \text { preserved) }\end{array}$ & $\begin{array}{l}\text { Formation of large (cubic) crystal- } \\
\text { line structures }\end{array}$ & Strong thermal alteration \\
\hline 3 & Strong, brown-grey & $\begin{array}{l}\text { Microstructure destroyed }(0 \% \\
\text { preserved) }\end{array}$ & $\begin{array}{l}\text { The granular structure has com- } \\
\text { pletely disappeared }\end{array}$ & Very strong thermal alteration \\
\hline
\end{tabular}


Wahl 1981's scale was used to assess the level of burn marks on animal bones and the guidelines according to the OssoBook database was used (Peters 2021).

\section{Results}

During the geoarchaeological and histotaphonomic assessment of the three sites, micro-layers were defined, described and correlated with the division into archaeological strata (Lo Russo 2021a, 2018; Rentzel 2011). The micro-layers were categorised into microfacies types based on the micromorphological and histotaphonomic results (Table 4, Fig. 5), providing a basis for comparing and interpreting microfacies from different sites. The microfacies will be briefly described hereinafter.

\section{Biesheim}

\section{Microfacies BIES 1}

Compact, silty fine sand, mainly composed of quartz, feldspar, mica, carbonates and a calcareous silt fraction.

\section{Microfacies BIES 2}

Compact, silty fine sand, mainly composed of quartz, feldspar, mica, carbonates and a calcareous silt containing some bone splinters, small fragments of tiles, stone fragments and charcoal (Fig. 6, Fig. 7).

\section{Microfacies BIES 3}

Silty fine sand, mainly composed of quartz, feldspar, mica, carbonates and a calcareous silt, with quicklime, hydraulic mortar and fragments of ceramics and non-local building stones (Fig. 6).

\section{Microfacies BIES 4}

A sequence of silty, fine sand, mainly composed of quartz, feldspar, mica, carbonates and a calcareous silt and silty crusts rich in micro-charcoal (fining upwards) (Fig. 7).

\section{Microfacies BIES 5}

Layered, compact, calcareous, sandy silt, mainly composed of quartz, feldspar, mica, carbonates and a calcareous silt containing micro-charcoal, charcoal, very few

Table 4 Micromorphological results for the Mithraeum of Biesheim, the cult cave of Zillis and the Mithraeum of Kempraten

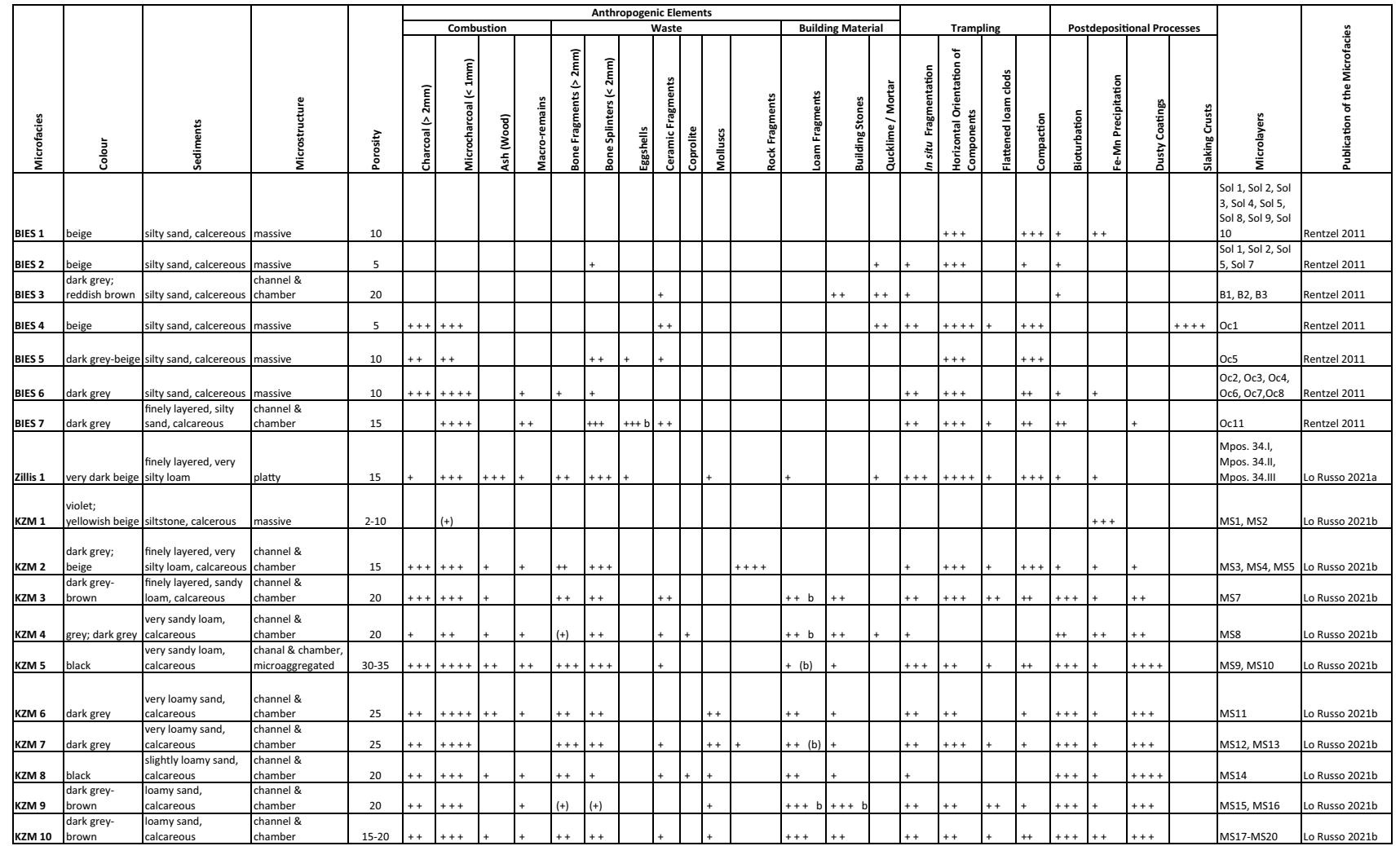


Fig. 5 Number [ $\mathrm{n}]$ of bones observed within the thin sections per microfacies. The percentages of bones with different heat alterations (colour code) and bacterial attack (hatching) are displayed for each size category. Here, the results for the bacteria attack were summarised for a better understandattack; $\mathrm{BAI}=3-4$, clear to little bacterial attack; $\mathrm{BAI}=5$, no bacterial attack (no putrefaction) ing: $\mathrm{BAI}=0-2$, heavy bacterial
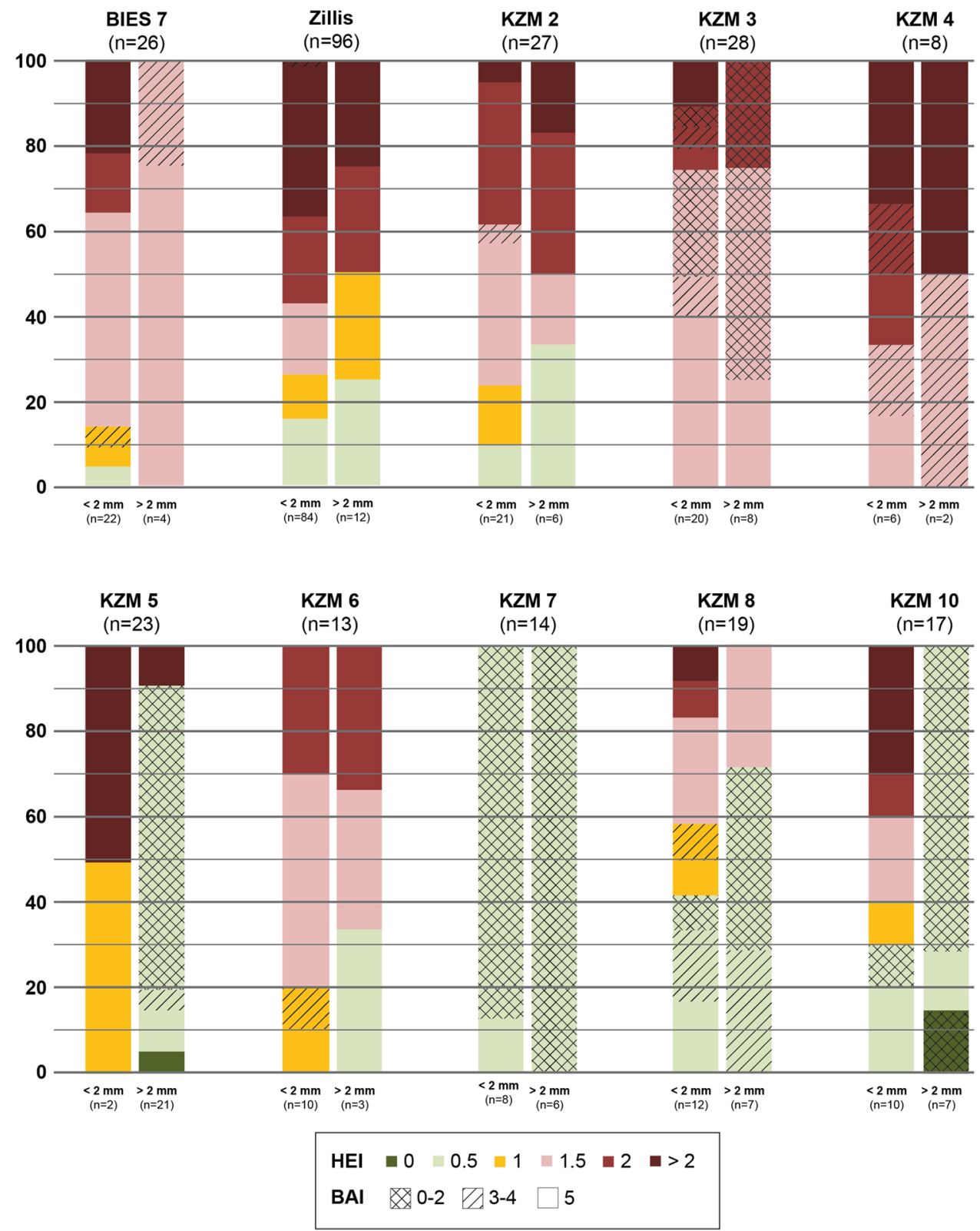

ceramic fragments and very few, usually burnt bone fragments and splinters (Fig. 6).

\section{Microfacies BIES 6}

A thin layer of micro-charcoal containing very few slightly burnt bone fragments and splinters. This microfacies differs from BIES 5 mainly because it contains more micro-charcoal.

\section{Microfacies BIES 7}

A finely layered, sandy deposit containing some horizontally oriented micro-charcoal, ceramic fragments, bone fragments and splinters (Fig. 8), and a large number of eggshells, most of which are slightly to strongly burnt. The bones rarely show any bacterial attack (Fig. 5).

\section{Zillis}

\section{Microfacies Zillis 1}

Microfacies Zillis 1 consists of various micro-layers, which differ in their ash and charcoal content as well as the frequency of components larger than $5 \mathrm{~mm}$ (Table 4). The individual micro-layers can be traced for several centimetres (Fig. 7). The microfacies is conspicuously fine-layered and contains horizontally oriented (micro-) components, some 
Fig. 6 Floor sequence inside the Mithraeum of Biesheim. A sandy loam floor with trampled bone and ceramic at the base (BIES 2) is covered by a silty activity surface (BIES 5) and a successive sandy loam floor (BIES 3). BIES 3 contains mortar fragments and is overprinted by construction activities. Left: PPL; right: XPL

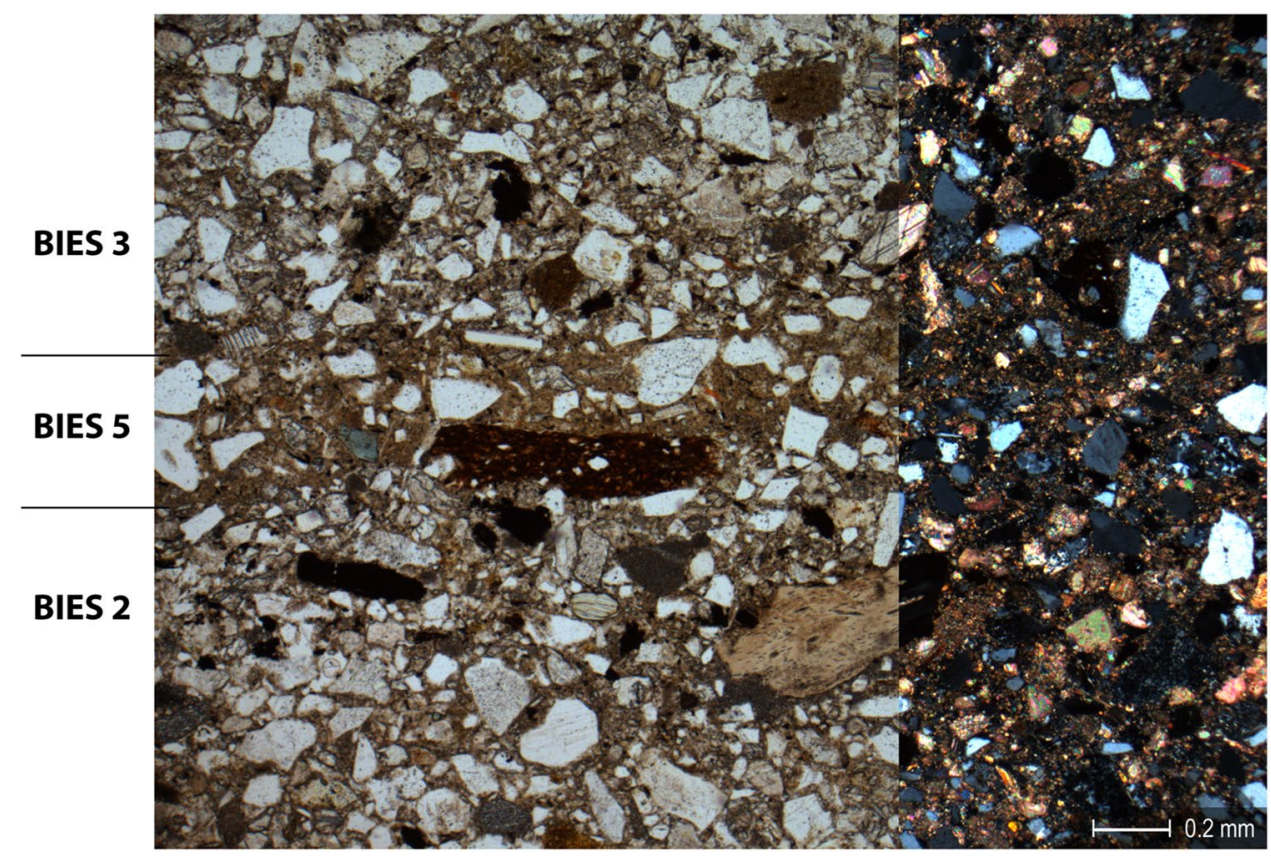

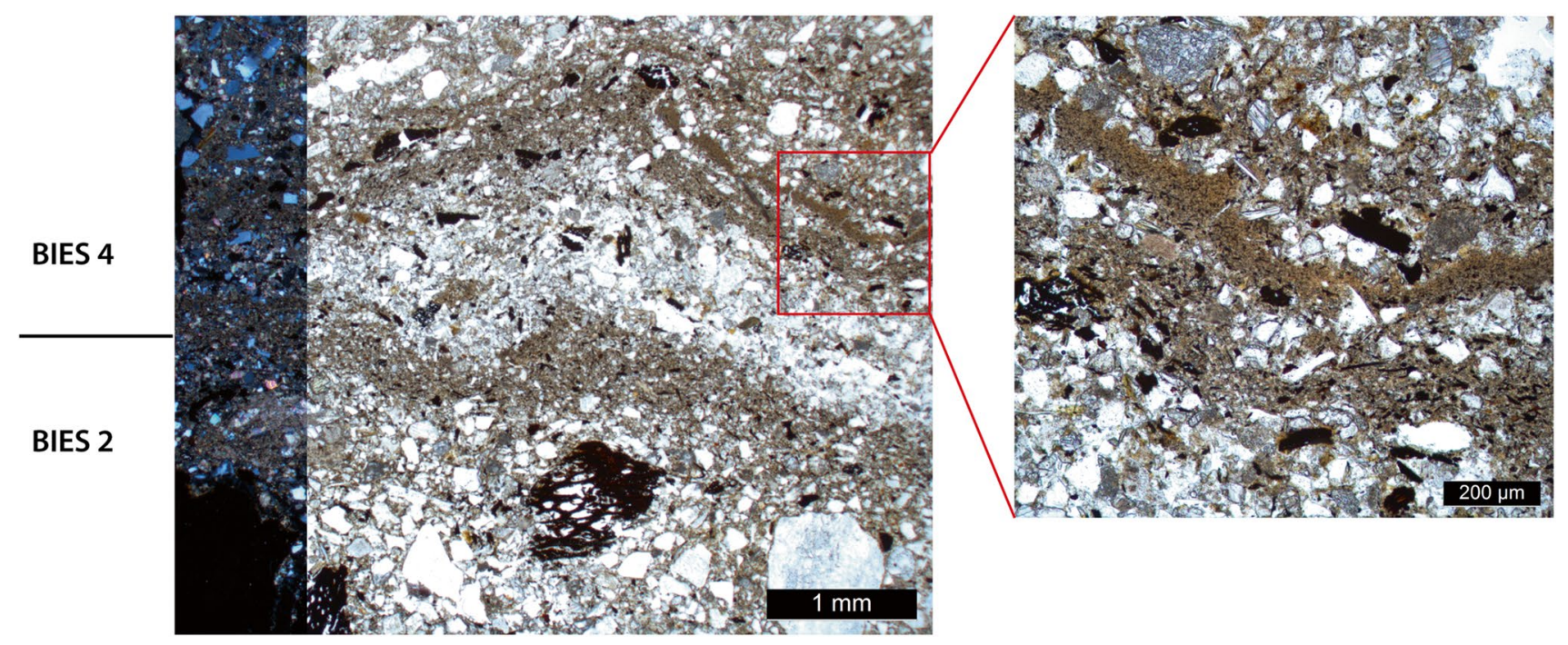

Fig. 7 A sandy loam floor with charcoal fragments at the base (BIES 2) is covered by a sequence of silty fine sand and silty crusts rich in microcharcoal (BIES 4). Left part of the left picture: XPL, right part of the left picture and right picture: PPL

of which were fragmented in situ. Besides ash and charcoal, the microfacies also very frequently contains bone splinters and rarely bone fragments (Fig. 9; Fig. 10). The bones observed in the thin sections were either heavily burnt or even calcined. Only a single bone showed signs of bacterial attack (Fig. 5).

\section{Zooarchaeology}

140 bone fragments from three fractions were found (1-2 $\mathrm{mm}, 2-5 \mathrm{~mm}, 5-10 \mathrm{~mm}$ ). Their average weights are between 0.004 and $0.09 \mathrm{~g}$ (Table 5). As could be expected, the coarser the fraction, the heavier the weight of the fragments. Nevertheless, it should be noted that they are all quite light.

Two fragments show black discolouration, which suggests that they were subjected to temperatures between approximately 300 and $600{ }^{\circ} \mathrm{C}$. A larger amount of bone fragments is white (Fig. 11), which is indicative of temperatures above $650{ }^{\circ} \mathrm{C}$ (Wahl 1981). A total of $50 \%$ of the bones in the smallest fraction and $30 \%$ of the middle fraction are white. None of the bones in the largest fraction ( $>5 \mathrm{~mm}$ ) shows 
Fig. 8 Density of bone fragments and splinters in the examined microfacies (number of bone fragments and splinters in relation to the observation area)

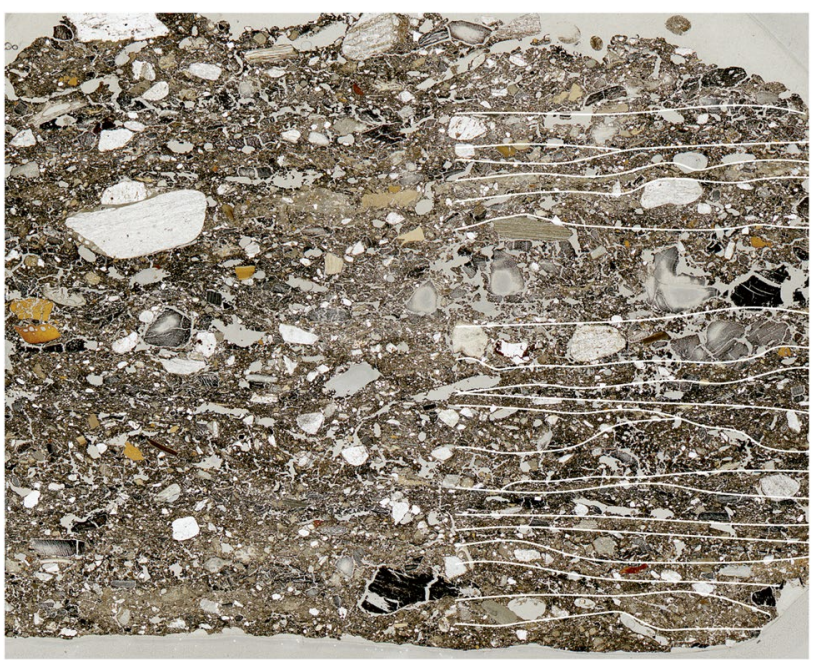

Fig. 9 Thin section scan of Zillis 1 with its micro-layers (frame $=40 \mathrm{~mm}$ ). Left: original scan; right: indication of micro-layers within microfacies Zillis 1

burn marks. This corresponds to the findings for bones collected by hand, where burn marks were almost inexistent (on average $<1 \%$ ) (Deschler-Erb and Stopp 2021).

Only two fragments from the fractions with fragments smaller than $2 \mathrm{~mm}$ could be clearly determined: parts of the sternum of a chicken (Gallus gallus domesticus) and the petrous part of the temporal bone of a mammal. For the remaining fragments, the class could be determined at most (Fig. 12). The ratio between mammal and bird remains in the three fractions corresponds more or less to the ratio for bones collected by hand (Deschler-Erb and Stopp 2021).

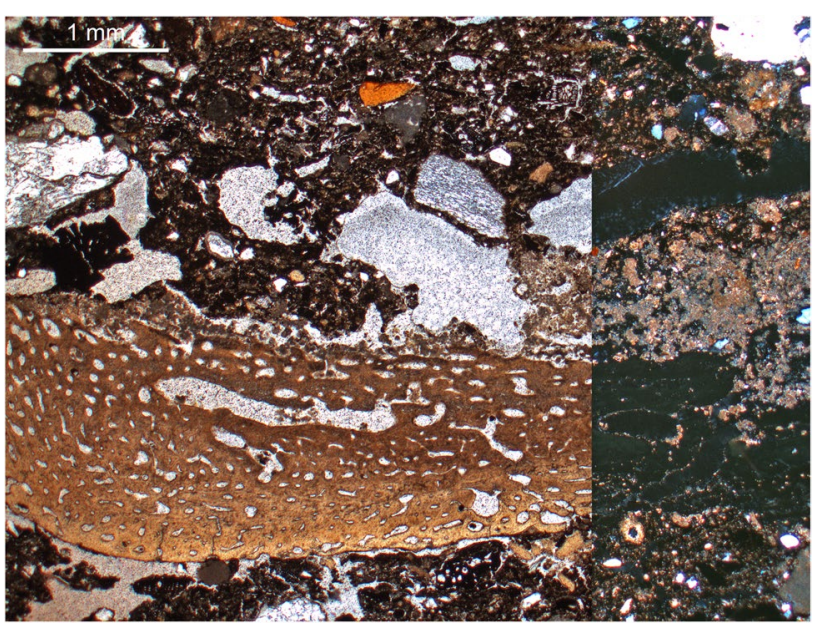

Fig. 10 Photomicrograph of a horizontally orientated, burnt bone fragment that was deposited along with ashes on the floor of the cult cave. Ash is also present within the cavities of the bone. Left: PPL; right: XPL

Bones from both classes show burn marks; however, the percentage of mammal bones with burn marks is far higher

Table 5 List of hand-collected and sieved bones from sample Zillis 1

\begin{tabular}{llll}
\hline Fractions & $n$ & Total weight $[\mathrm{g}]$ & $\begin{array}{l}\text { Average } \\
\text { weight }[\mathrm{g}]\end{array}$ \\
\hline $1-2 \mathrm{~mm}$ & 65 & 0.25 & 0.004 \\
$2-5 \mathrm{~mm}$ & 65 & 1.75 & 0.027 \\
$5-10 \mathrm{~mm}$ & 10 & 0.87 & 0.087 \\
Total & 140 & 2.87 & 0.021 \\
\hline
\end{tabular}


Fig. 11 Frequency of burnt bones in different sieve fractions of sample Zillis 1
Fig. 12 Frequency of animal taxa in different sieve fractions of sample Zillis 1
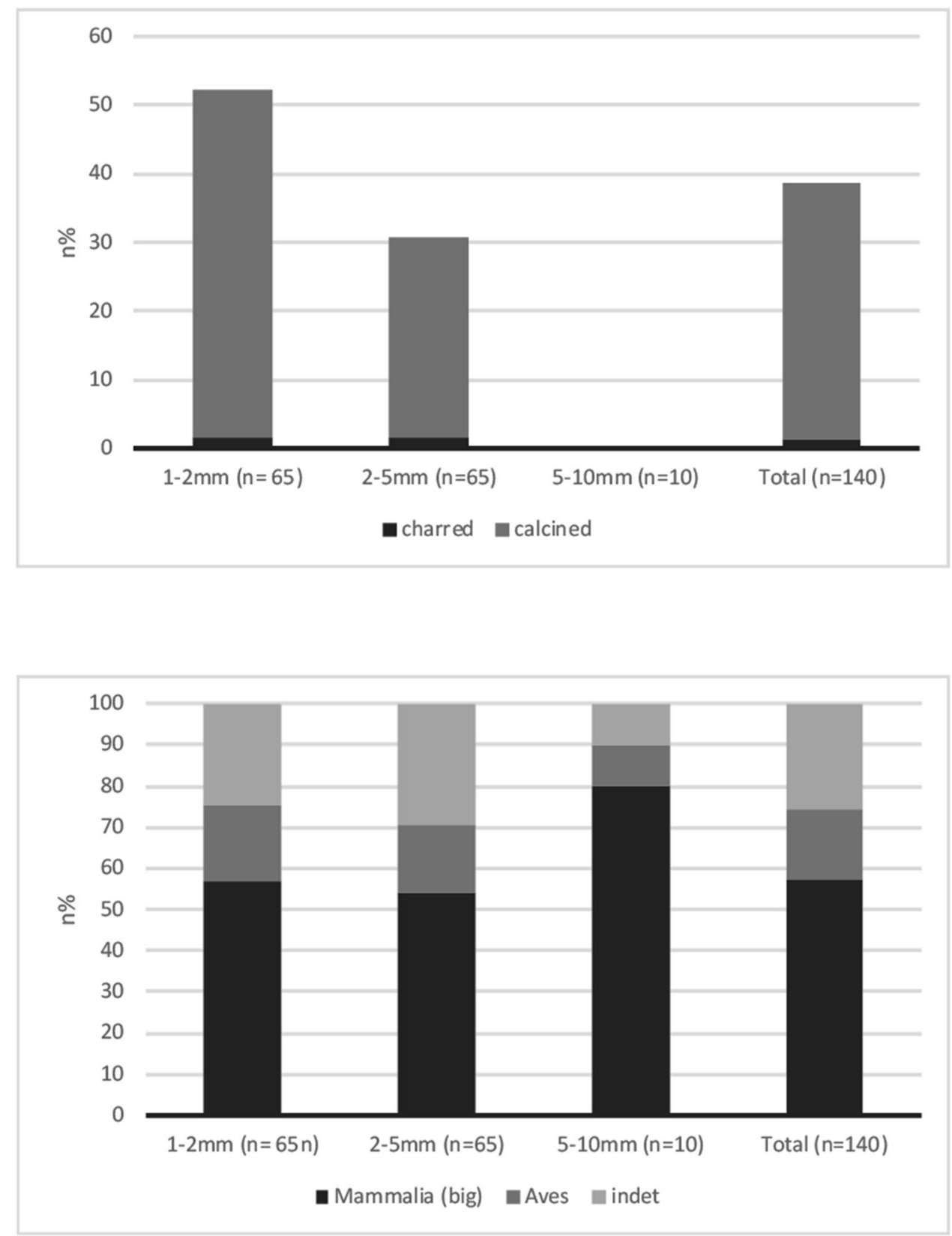

(Fig. 13), meaning mainly mammal bones were subjected to fire in Zillis.

\section{Kempraten}

\section{Microfacies KZM 1}

Calcareous siltstone (Miocene).

\section{Microfacies KZM 2}

In KZM 2, the percentage of siltstone fragments decreases towards the top while the percentage of horizontally layered, anthropogenic layer components - bone fragments and splinters and (micro-) charcoal - as well as the compaction of the sediments increase (Table 4). The bones, most of them bone splinters, tend to exhibit high levels of thermal alteration. Traces of bacterial attack are very rare (Fig. 5).

\section{Microfacies KZM 3}

Microfacies KZM 3 tends to contain sand and gravel as well as a number of building materials (building stone fragments, clay), which show traces of heat exposure (Table 4). Charcoal is also common. The bone density is lower than in KZM 2 (Fig. 8). All of the bones are burnt, with the thermal alterations 
Fig. 13 Frequency of burnt bone fragments per taxon in sample Zillis 1

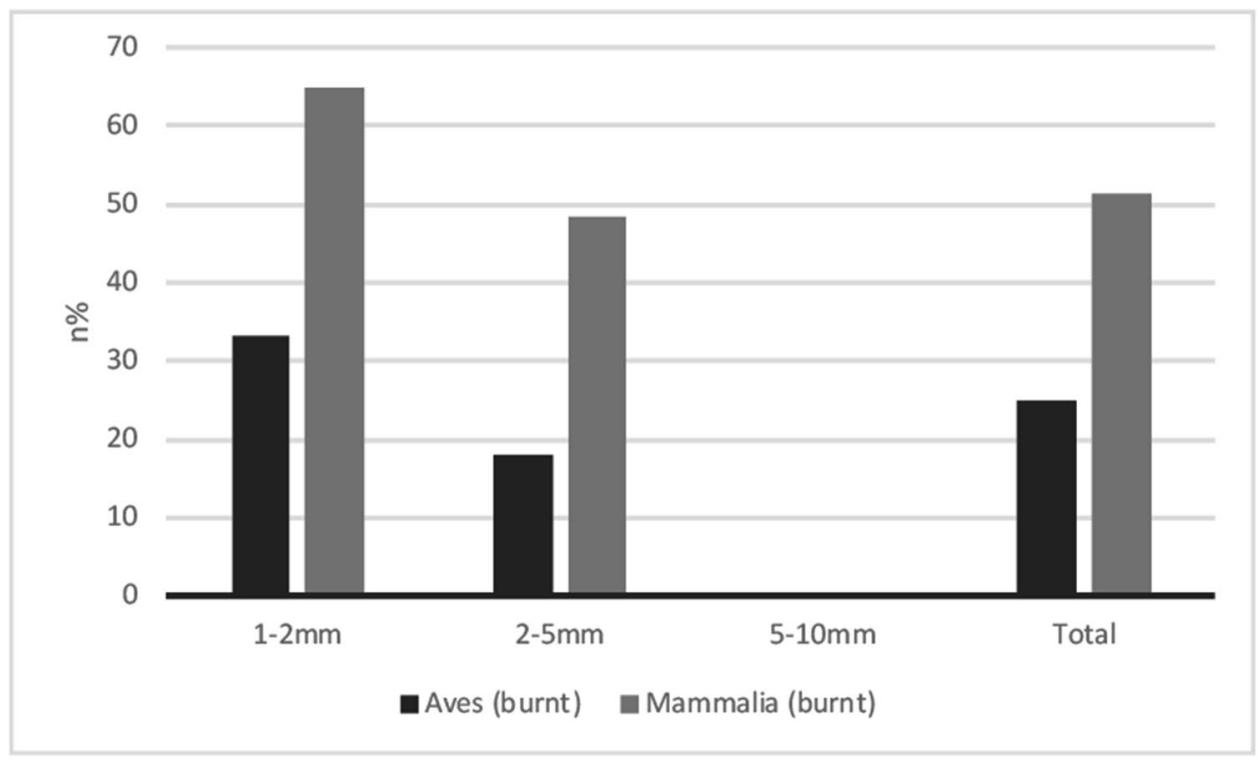

ranging from slightly burnt to calcinated. Most of the less burnt bones exhibit some signs of bacterial attack (Fig. 5).

\section{Microfacies KZM 4}

Microfacies KZM 4 is not stratified and contains building material such as building stones, clay fragments and mortar, which frequently show signs of thermal alteration (Table 4). (Micro-) charcoal, bone fragments and bone splinters are rare (Fig. 8). As in KZM 3, all bones are burnt without exception, though the degree of thermal alterations differs. The very heavily burnt and calcinated bones do not show any traces of bioerosion while the bones ranging from slightly to heavily burnt frequently exhibit signs of bacterial attack (Fig. 5).

\section{Microfacies KZM 5}

The largely not layered microfacies KZM 5 contains a lot of relatively large, fragmented charcoal and unburnt bone fragments with signs of bacterial attack (Fig. 14). Only few burnt bone splinters were found (Fig. 5). Microfacies KZM 5 has a high porosity and shows no signs of sediment compaction (Table 4).
Fig. 14 Thin section scan (48 mm wide; inset) and microscope photograph. KZM 5 and KZM 6 are visible in the scan. A pig's milk tooth (T), which is still completely enclosed in the jawbone (B), is visible in KZM 5. The jawbone shows intense bacterial attack (arrows)

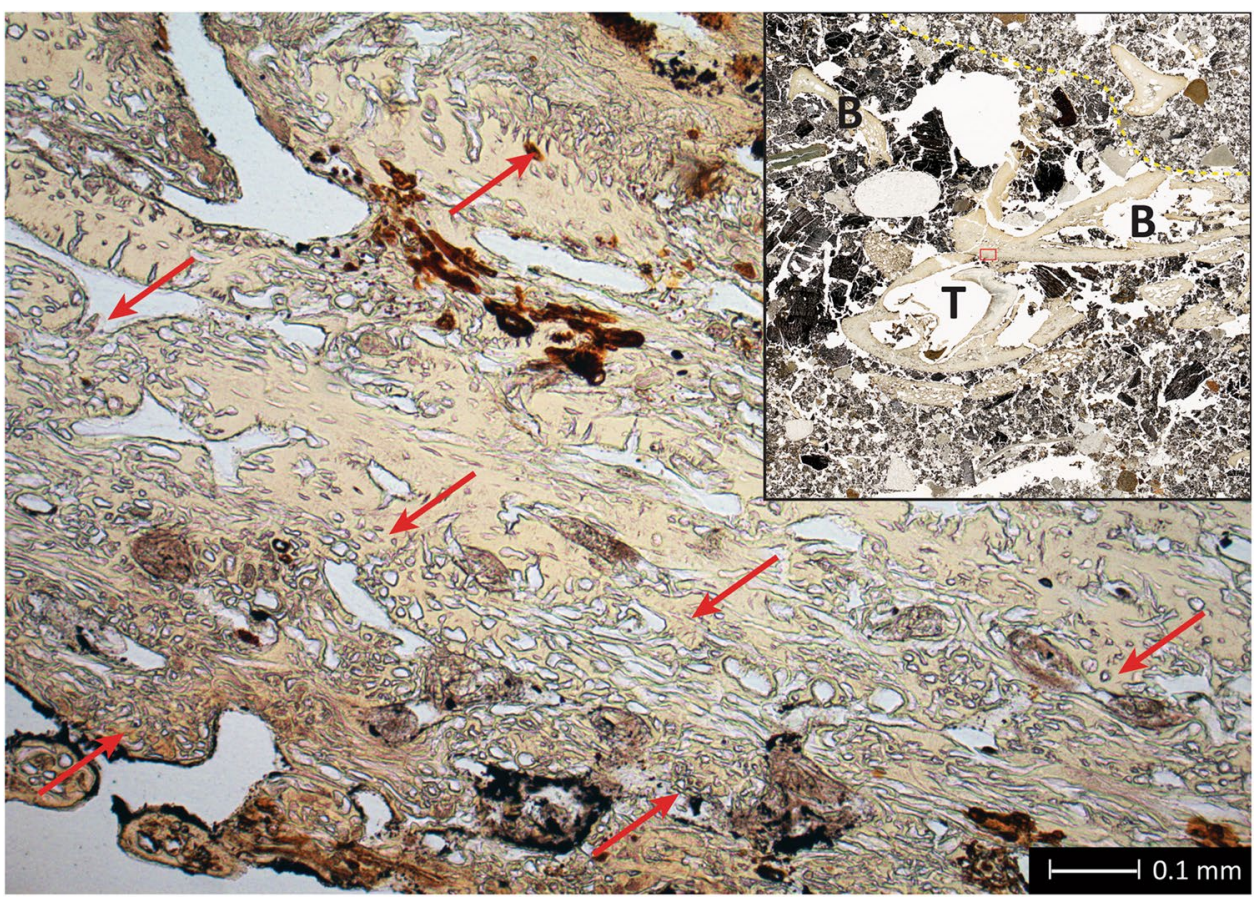




\section{Microfacies KZM 6}

The microfacies KZM 6 is highly porous and not layered (Table 4). Charcoal and bones are far rarer than in microfacies KZM 5 (Fig. 8) and most of them are burnt. Bone splinters are more common than bone fragments, the latter ranging from unburnt to slightly burnt. Only few cases of bacterial attack were found in microfacies KZM 6 (Fig. 5).

\section{Microfacies KZM 7}

The components in microfacies KZM 7 (charcoal, bones, few ceramic fragments and small pieces of rocks) show a slight horizontal orientation and in some cases in situ fragmentation (Table 4). Bones - all of them unburnt or slightly burnt - are again common with most of them showing strong or very strong signs of bacterial attack (Fig. 5).

\section{Microfacies KZM 8}

The components in microfacies KZM 8 (esp. bones and charcoal) show inconsistent orientation (Table 4). The unburnt to slightly burnt bones show bacterial attack while more heavily burnt bones (mostly bone splinters with HEI > 1) do not show any signs of bioerosion (Fig. 5).

\section{Microfacies KZM 9}

The layer components of this microfacies show signs of heat exposure as well as weak trampling (horizontal orientation of the components, flattened chunks of clay) (Rentzel et al. 2017). Building stone fragments are comparatively frequent (Table 4). Bone fragments and splinters do not occur in this microfacies, or at least only in bioturbation tunnels.

\section{Microfacies KZM 10}

Microfacies KZM 10 is characterised by an elevated amount of minerogenous elements, in particular sand. Bones, charcoal, strongly decomposed organic matter, ceramic fragments and building stone fragments make up the anthropogenic elements of these layers (Table 4). Most of the bone splinters are burnt and do not show any sign of bioerosion. Bone fragments are only slightly burnt or not at all and generally show a high level of bacterial attack (Figs. 5 and 8). The micro-layers of this microfacies show signs of trampling (compaction of the sediments, horizontal orientation of components).

\section{Discussion}

\section{Interpretation of the Microfacies}

\section{Biesheim}

A sequence of 11 loam floors was analysed in the central aisle of the Mithraeum of Biesheim (Table 6). The floors show a passive (BIES 1) and a reactive (BIES 2) zone (sensu Gé et al. 1993). Compact, loamy layers which repeatedly contain small fragments of building materials (BIES 3) were found in three layers and have been interpreted as construction levels. Depositional crusts containing micro-charcoal (BIES 4) were detected only on top of the lowermost loam floor (BIES 2) (Figs. 6 and 7). This could indicate that the ground was cleaned or flooded/wetted (Bresson and Valentin 1994; Lisá et al. 2020).

Apart from the compaction of the sediments, there are almost no traces from trampling or the general use of the loam floors in the form of micro-components (BIES 5). The recorded micro-components are almost exclusively microcharcoal without any clear evidence of wood ashes (BIES 6). This sequence of conspicuously "clean" loam floors suggests that the floors were either cleaned regularly or that some kind of cover was used (e.g. mats).

The uppermost layer BIES 7 looks completely different: a trampled, finely layered deposit of combustion residues, which includes heavily burnt animal bone splinters, few animal bone fragments and single burnt eggshells. The extensiveness of this layer as well as the homogenous size of the components suggest that BIES 7 should be interpreted as a sequence of levelling layers made of combustion residues that contained burnt bones and eggshells. It is possible that BIES 7 represents deposits on a final loam floor, which were left behind when the mithraeum was abandoned. Therefore, these deposits were not cleaned out before a new loam floor was brought in, as the corresponding older layers might have been. Alternatively, BIES 7 could represent a change in the (ritualistic) way in which the floors were made in the youngest phase: charcoal rather than loam floors was brought in.

\section{Zillis}

In the cult cave of Zillis, finely layered deposits (Zillis 1) made of combustion residues, which show clear signs of trampling, were analysed (Table 6). These layers are very well preserved (e.g. ashes show no traces of re-crystalisation). This made it possible to discern that the burnt bone splinters were spread on the ground along with the material rich in ash and micro-charcoal rather than trampled into the layer at a later point (Fig. 10; Lo Russo 2021a). The fact that all bone splinters, without exception, are burnt further 


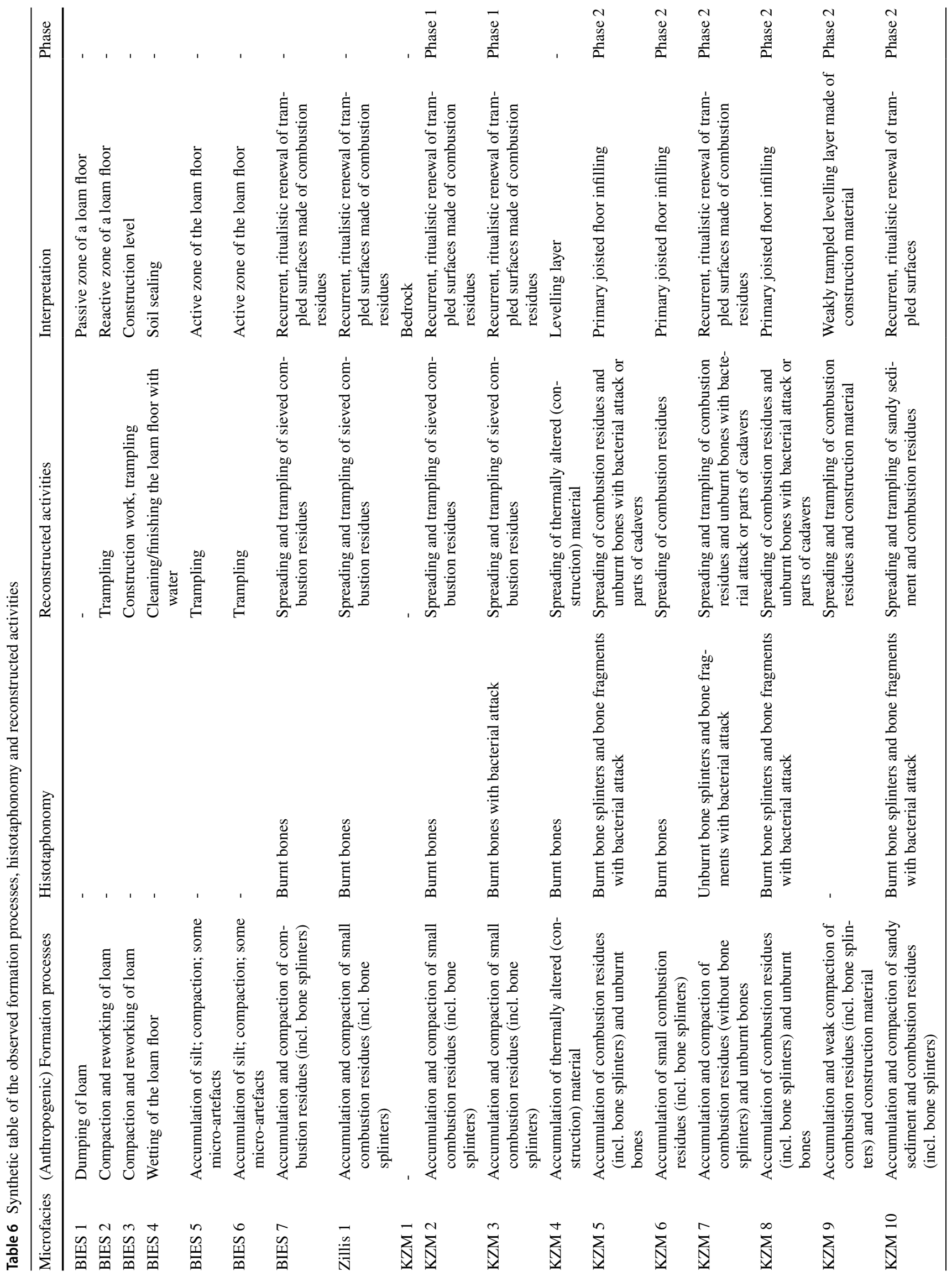


reinforces the impressions that the bone splinters form part of the combustion residues. This sequence of extensive, trampled levelling layers consisting of combustion residues was found throughout the cave.

Just as in Biesheim, the analysed microfacies (Zillis 1) is a sequence of thin levelling layers, consisting of ash, charcoal and burnt bone splinters. They can be interpreted as repeatedly renewed surfaces. Chunks of these heavily compacted charcoal floors were discovered outside the cave. It therefore seems likely that similar, older floor horizons were removed from the cult cave of Zillis. In the cave itself, more than 100 such charcoal floor levels were preserved in situ (Lo Russo 2021a).

\section{Kempraten}

The walked-on bedrock (KZM 1) is topped by a finely layered sequence of sediments containing large amounts of charcoal (KZM 2). The composition of the micro-layers in KZM 2 as well as the preservation of bone splinters and fragments is comparable to the microfacies BIES 7 and Zillis 1 (Figs. 4 and 6; Table 6). It therefore seems likely that KZM 2 also represents levelled off and trampled combustion residues.

The micro-layers of KZM 3 are the first to feature wellsorted medium sand, which was probably added in order to level off the surface. The bone density decreases significantly where this sand was added (Fig. 8). Microfacies KZM 3 and KZM 4 also contain several heavily burnt animal bones that exhibit intense bacterial attack (Fig. 5). This is unusual for "normal" consumption waste (Brönnimann et al. 2018; Jans 2005): when animals are slaughtered for consumption, the body parts are cut off almost immediately after death. This leads to no or low bacterial attack. In this case, the intense bacterial attack suggests that the bones do not represent consumption waste. Instead, they probably stem from animal cadavers (slow decomposition of the entire body leads to intense bacterial attack) (Brönnimann et al. 2018; Jans 2005). It can therefore be assumed that processes or activities other than slaughter led to animal remains, or parts thereof, being taken into the mithraeum. The animal bones were subjected to intense heat at a different point. The fact that a construction timber from phase 1 (KZM 2 and KZM 3) was burnt in situ near the western podium indicates that the cult building was destroyed by a fire (Ackermann et al. 2020). It could therefore be that the thermal alteration on the bones stemming from an already decomposing animal (KZM 3) is purely "accidental" and the result of such a fire. However, as the sediments in KZM 3 do not show any signs of such extreme heat exposure, it seems more likely that these burnt bones were in fact spread in the central aisle at the same time as other combustion residues and sand.
From a stratigraphic point of view, KZM 4 constitutes the transition to phase 2. However, it does not represent a building horizon, because there are no signs of unburnt building material or trampling. A high porosity and a high frequency of larger charcoal and bone fragments in KZM 5 indicate that this microfacies was used to fill in the area underneath a joisted wooden floor (Lo Russo 2021b). KZM 6 also shows few signs of direct trampling (Table 4) and contains only very small components. It therefore seems likely that this represents a secondary infilling underneath a joisted floor (Lo Russo 2021b).

From a histotaphonomic perspective, the two infillings not only differ regarding the size of the fragments (Fig. 8) but also regarding the amount of heavily burnt bones and the frequency of bacterial attack in the bones (Fig. 5). The histotaphonomic parameter of the bones from KZM 6 (secondary joisted floor infilling) is comparable to those in Zillis 1, Bies 7 or KZM 2 (Fig. 5). In contrast, the primary joisted floor infilling KZM 5 contains mainly unburnt bone fragments with heavy bacterial attack (which, based on zooarchaeology, include a young pig; Fig. 14). These bone fragments like the ones in KZM 3 and KZM 4 - are to be interpreted as the remains of animal cadavers. However, unlike the bones in KZM 3 and KZM 4, the animal cadaver remains in KZM 5 are only slightly burnt or not at all. Although burnt bones are missing in KZM 5, (micro-) charcoal is an important component. In this respect, KZM 5 resembles KZM 7. While bone splinters may be more frequent in KZM 7, these are likely to be pieces of larger bone fragments, as the histotaphonomic alterations (high intensity of bacterial attack and no signs of thermal alterations) mirror those of the larger bone fragments from KZM 5. It is likely that this led to an inflated bone density as it is the number of fragments rather than their size that was used to determine this factor (Fig. 8).

The greater fragmentation of bones in KZM 7 corresponds to the micromorphological observations, which suggest that the microfacies experienced direct trampling and that there was therefore another change in the type of floor installation. Just as in KZM 3, sand again represents an important layer component. The lack of any signs of direct trampling in KZM 8 as well as the archaeologically proven presence of a sub-structure for an elevated, wooden floor indicates that this microfacies was yet another joisted floor infilling (Lo Russo 2021b).

The above-average heterogeneity, the high share of building material and the weak signs for trampling suggest that KZM 9 represents a levelling layer made of building material that was hardly walked on (Lo Russo 2021b). After the removal of the wooden floor, the levelling layer KZM 9 filled in the cavity between the retaining walls and the joists. On top of this lie the directly trampled sandy loam floors KZM 10. The bone density in these sandy floors is low (Fig. 8). The composition 
of the anthropogenic elements of KZM 10 resembles the one of KZM 8, although the two deposits developed on and underneath very different kinds of layers.

\section{Let's talk about bones}

Our interdisciplinary study has shown that the combination of macroscopic (zooarchaeology) and microscopic (histotaphonomy) research methods regarding bone analysis presents a promising approach. The find inventory of Zillis lends itself particularly well to this combination of macroscopic and microscopic research methods due to its high number of bones and the outstanding preservation of its layers.

\section{Methodological Aspects}

Using zooarchaeology and histotaphonomy in conjunction also revealed some (methodological) difficulties. It is not easy to compare zooarchaeological and histotaphonomic data if only the bones collected by hand are analysed zooarchaeologically. This is because they are larger than the ones contained in (geoarchaeological) thin sections. For the histotaphonomical and zooarchaeological analysis of the finds from the cult cave of Zillis, this problem was resolved by focusing on smaller bone fragments $(2-5 \mathrm{~mm})$ and splinters $(<2 \mathrm{~mm})$ that were taken from the sieving material left over from the sediment analyses.

Comparing the results relating to thermal alteration also posed a challenge. Zooarchaeological analysis demonstrated that an estimated $50 \%$ of small bone fragments $(2-5 \mathrm{~mm})$ and bone splinters $(<2 \mathrm{~mm})$ were burnt. The histotaphonomic analysis puts this percentage much higher, between 70 and $100 \%$ (Fig. 5). These substantially differing estimates are likely due to the fact that different methods were used: discolouration of the bone surface for zooarchaeological analysis, versus alterations to the bones' microstructure, recrystallisations and the collagen content as part of the histotaphonomic analysis. This broader range of criteria allows less obvious indicators to be detected. Interestingly, based on the histotaphonomic analysis, approximately $50 \%$ of bones were heavily burnt (HEI 2-3) (Fig. 5). This corresponds to the zooarchaeological estimate and leads us to believe that only intense burn marks are identified macroscopically. Less extreme heat exposure (HEI 1-1.5) is only detected using additional methods.

\section{The Difference between Larger Bone Fragments and Bone Splinters}

Based on our findings, it appears that all small bone fragments $(2-5 \mathrm{~mm})$ and bone splinters $(<2 \mathrm{~mm})$ from the cult cave of Zillis were subjected to heat, with about half experiencing extreme heat exposure. This observation stands in stark contrast to the zooarchaeologically analysed larger bone fragments ( $>5 \mathrm{~mm}$ ) from the same site, which do not show any signs of fire exposure (Fig. 11). Thus, the cult cave of Zillis contained a large number of generally unburnt, larger bone fragments but also numerous (heavily) burnt bone splinters, which were embedded in the floors along with wood ash and charcoal fragments of a comparable size. This disparity cannot be explained by the methodological differences alone. Instead, it is an indicator that animal bones from the cult cave of Zillis were treated in two different ways.

(Unburnt) larger animal bones have already been found in other mithraea (and similar cultic sites). They have generally been interpreted as food remains from ceremonies and cult banquets (Olive 2008). However, the presence of heavily burnt bone splinters is a phenomenon that had not been observed before. Nevertheless, being present on all three sites under study, the phenomenon appears to represent a recurrent activity, which had so far been wholly unheard of. How these activities should be interpreted remains unclear. A number of possible scenarios will be discussed below.

\section{Remains of burnt offerings?}

The burning of plant offerings and incense inside the cult room of mithraea is attested by images and features (Bird 2004). The burning of pieces of meat with bones or animal bones - so called bleeding burnt offerings (Scheid 2007) - was recently recognised as part of the Mithraic cult practices by McCarthy et al. According to this study the (burnt) bones and combustion residues found in a box underneath the floor are to be understood as a so-called foundation deposit (McCarty et al. 2019). This cult practice has been recorded in many other mithraea. By contrast, regular animal offerings are currently not understood as part of the Mithras cult. Burnt animal offerings do however form part of other oriental cults, namely the Isis and the Magna Mater Cult (Hochmuth et al. 2005; Hochmuth and Witteyer 2008; Koch et al. 2018).

Bird bones, and rarely mammal bones, were burnt in a temple dedicated to Magna Mater in Kempraten, Seewiese (altar Pos. 1 and hearth Pos. 139) (Koch et al. 2018). The share of calcined bones ( $2 \mathrm{~mm}$ fraction) is considerably higher (80\%) (Hüster Plogmann unpublished) than that for the animal bone fragments and splinters found in Zillis $(30-50 \%)$. Furthermore, size and medium fragment weights, which also determine whether or not an animal bone can be assigned, are far greater for bones from such altars or cremation burials (Koch et al. 2018) than those for the burnt bone fragments from the cult cave of Zillis or the microfacies KZM 2, KZM 3 and BIES 7 (Baerlocher et al. 2013; Koch et al. 2018; Romano and Voyatzis 2014). 
However, these disparities could suggest that the phenomenon of heavily burnt, small bone fragments as found in the cult cave of Zillis and the Mithraea of Kempraten and Biesheim do not constitute the same kind of burnt offerings as are known from other Roman cultic contexts. This does not necessarily mean that the findings analysed as part of this study are not burnt offerings. Cult-specific differences could also have resulted in these disparities. Furthermore, the peculiarities of the bones even suggest that the observed phenomenon is the result of a very specific series of activities.

\section{Remains from a Cult Meal or a Fire Ritual?}

Extreme thermal alteration of bone fragments and splinters - in some cases due to temperatures above $700-900{ }^{\circ} \mathrm{C}$ or a long duration of burning (Lambrecht and Mallol 2020; Snoeck et al. 2014; Squires et al. 2011; Symes et al. 2013; Stiner et al. 1995) - is an important characteristic observed on all three sites. Other peculiarities are the presence of charcoal and the extraordinarily high but surprisingly uniform level of bone fragmentation, especially in the case of the microfacies Zillis 1, KZM 2, KZM 3 und BIES 7. Based on the high proportion of (very) heavily burnt bones $\left(\mathrm{HEI}=2-3 ; 600-900{ }^{\circ} \mathrm{C}\right.$, or $>900{ }^{\circ} \mathrm{C}$ ) and heated eggshell in the case of BIES 7, it is unlikely that they are remains from food preparation (e.g. a cult meal), even though such temperatures are not unusual within a hearth or open fire (Pérez et al. 2017). Meat on bones or animal bones on their own was burnt in this fire. Researchers such as Stiner et al. (1995) have found that burnt bone is more fragile and calcined parts of incompletely burnt bones are prone to breaking off when suffering mechanical pressure (e.g. through trampling or sieving). Additionally, the conspicuously homogenous fragmentation of bone splinters and charcoal suggests that they were part of hand-selected or sieved residues of a fire. It remains unclear what happened to the oversized material as only the smallest combustion residues were found on site.

To sum up, the characteristics observed on all three sites (homogenous sorting of combusted components, lack of other food remains and absence of burnt loam fragments) are indicative of a minutely ritualised activity with clear rules. Our results suggest that the bones were burnt at high temperatures. The combustion residue was then sorted or sieved, spread on the floor and walked on. The finely layered sequence in the cult cave of Zillis clearly shows that these activities were repeated several times. Thus, it appears this was a clearly defined, "fire ritual". How exactly this ritual is to be interpreted and which aspects where at the centre of the activity remain unclear (burnt material as "offering", fire as a cleansing element or a symbol of transformation, etc.).
The deposition of (remains of) cadavers as ritual action?

The postulated "fire ritual" is not the only multi-stage practice that we were able to make visible by combining archaeology, zooarchaeology and histotaphonomy. In Kempraten (KZM 3-4), heavily burnt bone fragments and splinters that exhibited intense bacterial attack were found (Fig. 5). The intense bacterial attack suggests that these bones do not constitute "ordinary" consumption waste; instead, they stem from one or more cadavers - remains of whole decomposing animals - that were burnt at high temperatures. Thus, the assumption that the bones represent food remains can be ruled out, at least for those two microfacies.

In phase 2 of the Mithraeum of Kempraten (KZM 5, 7, $8,10)$, several unburnt bone fragments with high levels of bacterial attack were recorded (Figs. 4 and 12). These have been interpreted as parts of several cadavers - including at least one from a young pig. The cadaver remains, along with charcoal, were deposited underneath the floorboards in the cult room and trampled into the sandy loam floors. In contrast to the heavily burnt bones, larger fragments of these unburnt cadaver remains were preserved as well. It appears that the bones were not sorted according to size, as was the case for the combustion residues. Thus, the spreading of bones/bone fragments stemming from cadavers or parts of cadaver is another practice that had not yet been observed in other contexts.

Our interdisciplinary approach shows that animals, or animal bones, played an important role in the mystic cult practices and that they are not always to be interpreted as food remains from a cult meal.

\section{Renewal of the floors}

On all three sites, combustion residues were repeatedly spread on the ground of the cult rooms and walked on. Spreading combustion residues in order to dry and clean floors is a practice recorded by various archaeological and ethnographic sources from other regions and times (Hakbijl 2002; Milek 2012; Milek and Roberts 2013). However, it had not been observed in a (provincial) Roman context before. Whether (ritual) cleaning or renewal of the cult room was one of the motivations for spreading the combustion residues remains unclear. Fire shovels and representations thereof have been found in several mithraea (Becatti 1954; Ebnöther et al. 2021; Huld-Zetsche 1986; Richmond and Gillam 1951). As these shovels could have been used to spread the sieved combustion residues, they support the hypothesis that this way of handling combustion residues played an important role in the cult. As a result of being constantly walked on, these levelling layers fulfilled the functions of a charcoal floor that was regularly renewed. 
The use of combustion residues, such as ash, for construction of floors is so far only known from prehistoric Near East (Mentzer 2018; Mentzer and Quade 2012; Matthews and French 2005; Matthews et al. 1994) but is a very new finding for Roman Archaeology.

The surfaces which these floor layers cover show hardly any signs of contamination (e.g. introduced sediment chunks, coprolite fragments, "street dirt"). This leads us to conclude that these surfaces were either not made dirty or cleaned carefully before they were renewed. The fact that the renewed floors are clean and look as good as new is especially evident in Biesheim. There, the charcoal floors BIES 7 top a sequence of almost sterile loam floors. In the central aisle of the Mithraeum of Kempraten, the charcoal floors are superseded by elevated wooden floors and sandy loam floors. Nevertheless, combustion residues remain an important component in all floor types present in the Mithraeum of Kempraten. In our opinion, this suggests a ritual significance of these practices.

The recurrent floor renewals led to a significant level increase in both mithraea; however, the originally raised podia on either side of the central aisle were not raised further at the same time. This raises the question whether the central aisles were deliberately constructed in such a way as to allow for a gradual accumulation. The repeated renewal of the floors is not linked to an all-encompassing renovation of the building on a regular basis; the floors of the central aisle appear to be the only part of the building that was renewed regularly.

Two prominent examples of ritual practices related to the installing of floors in the central aisle exist: the mosaic floor of Ostia, which was donated as part of a vow (Becatti 1954), and the so-called foundation deposit. These foundation deposits, which often consist of charcoal and burnt animal bones, were deposited in boxes underneath the floor of the central aisle and have been found in more than 13 Mithraea throughout the Roman Empire (McCarty et al. 2019). It is telling that these rather conspicuous features are generally described in far greater detail than the floors themselves. This study shows once again that archaeological strata - in particular floors - deserve more attention than they are often given, as they contain important information about cult practices.

\section{Conclusion}

This interdisciplinary study has proposed a new and enhanced way of analysing the Mithras cult. Our integrated analyses (micromorphology, histotaphonomy and zooarchaeology) of the floor surfaces, sediments and findings have facilitated a first reconstruction of some of the activities related to the largely unknown cult practices of Mithraism (Table 6). Our study has shed light on a number of rituals consisting of several steps.

Histotaphonomic analyses have identified (parts of) animal cadavers underneath wooden floors in Kempraten. Larger bone fragments in Zillis and Biesheim have not yet been analysed histotaphonomically. Thus, the relation of these cadavers to the Mithras cult remains unclear. Even in the case of already excavated Mithras sanctuaries from which the animal bone finds still exist, studies such as ours can lead to increased meaningful insights. Hence, further histotaphonomic analyses will lead to a greater understanding of the many animal bones found in mithraea.

Our research emphasises that, in future excavations, archaeological strata should be a topic of investigation in the same ways as features and findings are. This approach has allowed us to observe multi-layered activities on all three sites. They appear to constitute important elements of the Mithras cult: the burning of animal bones and wood, the subsequent sieving of the combustion residues and the recurrent spreading of these sieved residues in the central aisle or cult cave. These levelling layers were trampled on all three sites. This trampling resulted in the combustion residues taking on the form of floor surfaces. On all three sites, the floors were regularly renewed, although the types of floors varied. This is yet another cult practice that has been detected for the first time within the scope of this study.

Acknowledgements This work was funded through the Institute of Archaeological Sciences (University of Bern) and Integrative Prehistory and Archaeological Science (University of Basel). We thank the Archäologische Dienst Graubünden, the Kantonsarchäologie St. Gallen and Prof. Peter-Andrew Schwarz for sampling the sites and giving us the opportunity to study this material. The authors would like to thank Christine Pümpin (University of Basel) and Barbora Wouters (Vrije Universiteit Brussel) for their advice and support. The thin sections were produced by Thomas Beckmann and Pascal Tschudin (University of Basel). Kantonsarchäologie St. Gallen provided the basis for the published maps and the layout of the Kempraten Mithraeum. Furthermore, we thank Olivia Klee for translating the text into English. Finally, we would like to thank Susan M. Mentzer and the anonymous referee for their valuable inputs and suggestions for the revision of the manuscript and figures.

Author contribution All authors contributed to the study conception and design. Material preparation, data collection and analysis were performed by SLR, DB, SDE and PR. The first draft of the manuscript was written by SLR, CE (The Late Roman cult cave in Zillis-Reischen), SDE (Zooarchaeology) and DB (Let's talk about bones). All authors commented on previous versions of the manuscript. All authors read and approved the final manuscript.

Funding Open access funding provided by University of Basel. The research leading to these results received funding from the Institute of Archaeological Sciences (University of Bern) and Integrative 
Prehistory and Archaeological Science (University of Basel). The Archäologische Dienst Graubünden and the Kantonsarchäologie St. Gallen provided the samples for our studies.

Data availability All data comply with field standards.

Code availability Not applicable.

\section{Declarations}

Conflict of interest The authors declare no competing interests.

Open Access This article is licensed under a Creative Commons Attribution 4.0 International License, which permits use, sharing, adaptation, distribution and reproduction in any medium or format, as long as you give appropriate credit to the original author(s) and the source, provide a link to the Creative Commons licence, and indicate if changes were made. The images or other third party material in this article are included in the article's Creative Commons licence, unless indicated otherwise in a credit line to the material. If material is not included in the article's Creative Commons licence and your intended use is not permitted by statutory regulation or exceeds the permitted use, you will need to obtain permission directly from the copyright holder. To view a copy of this licence, visit http://creativecommons.org/licenses/by/4.0/.

\section{References}

Ackermann R (2013) Der römische Vicus von Kempraten, RapperswilJona: Neubetrachtung anhand der Ausgrabungen Fluhstrasse 6 -10 (2005 - 2006). Archäologie im Kanton St. Gallen, vol 1. Amt für Kultur des Kantons St. Gallen, St. Gallen

Ackermann R, Akeret Ö, Deschler-Erb S, Häberle S, Lo Russo S, Peter M, Pümpin C, Schlumbaum A (2020) spotlighting left-overs: the mithraeum at Kempraten (Rapperswil-Jona, Switzerland): the interdisciplinary analysis project and initial results. In: McCarty M, Egri M (eds) The Archaeology of Mithraism: New finds and approaches to Mithras-worship, Leuven, pp 47-64

Alvar Ezquerra J (2008) Romanising oriental gods: myth, salvation and ethics in the cults of Cybele, Isis and Mithras. Religions in the Graeco-Roman World, vol 165. Brill, Leiden, Boston

Baerlocher J, Akeret Ö, Cueni A, Deschler-Erb S (2013) Prächtige Bestattung fern der Heimat -: Interdisziplinäre Auswertung der frührömischen Gräber der Grabung Windisch-«Vision Mitte» 2006-2009. Jahrbuch Der Gesellschaft pro Vindonissa 2012:29-55

Becatti G (1954) Scavi di Ostia: II: i mitrei, Roma

Bell LS (2012) Histotaphonomy. In: Crowder C, Stout S (eds) Bone histology: an anthropological perspective. CRC Press, Boca Raton, pp 241-251

Bell LS (1995) Post mortem microstructural change to the skeleton. a thesis submitted for the degree of Doctor of Philosophy, University of London

Bird J (2004) Incense in Mithraic ritual: the evidence of the finds. In: Martens M, Boe G de (eds) Roman Mithraism: The evidence of the small finds : [papers of the international conference ... Tienen 7 - 8 november 2001]. Instituut voor het Archeologisch Patrimonium, Bruxelles

Booth TJ (2014) An investigation into the relationship between bone diagenesis and funerary treatment. PhD Thesis, University of Sheffield

Bresson L-M, Valentin C (1994) Soil surface crust formation: contribution of micromorphology. In: Ringrose-Voase AJ, Humphreys GS (eds) Soil micromorphology: Studies in management and genesis: Proceedings of the IXth International Working Meeting on Soil Micromorphology, Townsville, Australia, July 1992, Amsterdam, pp 737-762

Brönnimann D, Portmann C, Pichler SL, Booth TJ, Röder B, Vach W, Schibler J, Rentzel P (2018) Contextualising the dead - combining geoarchaeology and osteo-anthropology in a new multi-focus approach in bone histotaphonomy. J Archaeol Sci 98:45-58. https://doi.org/10.1016/j.jas.2018.08.005

Clauss M (2001) The Roman cult of Mithras: the god and his mysteries, 1st edn. Taylor and Francis, London

Deschler-Erb S, Stopp B (2021) Tierknochen. In: Ebnöther C, Flückiger A, Peter M (2021) Zillis: Von der spätantiken Kulthöhle zum frühmittelalterlichen Bestattungsplatz. Mit Beiträgen von Sabine Deschler-Erb, Sarah Lo Russo, Barbara Stopp, Sönke Szidat und Jonas von Felten. Archäologie in Graubünden - Sonderheft, vol 10, Chur, pp 114-128

Devos Y, Paridaens N (2019) Etude micromorphologique sur le sanctuaire gallo-romain de « La Taille Marie » à Aiseau-Presles (Hainaut, B.). Signa 8:43-48

Ebnöther C, Flückiger A, Peter M (2021) Zillis: Von der spätantiken Kulthöhle zum frühmittelalterlichen Bestattungsplatz. Mit Beiträgen von Sabine Deschler-Erb, Sarah Lo Russo, Barbara Stopp, Sönke Szidat und Jonas von Felten. Archäologie in Graubünden - Sonderheft, vol 10, Chur

Fortuné C (2011) Le Mithraeum, une fouille ancienne revisitée. In: Reddé M (ed) Oedenburg, Volume 2: L'agglomération civile et les sanctuaires. Part 2: Matériel et études, Mainz, pp 227-255

Gé T, Courty M-A, Matthews W, Wattez J (1993) Sedimentary formation processes of occupation surfaces. In: Goldberg P, Nash DT, Petraglia MD (eds) Formation processes in archaeological context, Madison, Wisconsin, pp 149-163

Goldberg P, Macphail RI (2006) Practical and theoretical geoarchaeology. Blackwell Publishing, Oxford

Häberle S, Deschler-Erb S, Hüster Plogmann H, Stopp B, Lo Russo S, Koch P, Ackermann R (2021) Animals in ritual and domestic context: a comparative study between the faunal assemblages from residential areas and two sanctuaries at the vicus of Kempraten (Rapperswil-Jona, CH). In: Deschler-Erb S, Albarella U, Velenzuela Lamas S, Rasbach G (eds) Roman Animals in Ritual and Funerary Contexts: Proceedings of the 2nd Meeting of the Zooarchaeology of the Roman Period Working Group, Basel 1st-4th February, 2018. Harrassowitz, Wiesbaden, pp 79-99

Hackett CJ (1981) Microscopical focal destruction (tunnels) in exhumed human bones. Med Sci Law 21:243-265

Hakbijl T (2002) The traditional, historical and prehistoric use of ashes as an insecticide, with an experimental study on the insecticidal efficacy of washed ash. Environ Archaeol 7:13-22. https://doi.org/10.1179/env.2002.7.1.13

Hensen A (2017) Templa et spelaea Mithrae: topography, architecture and design of sanctuaries in the cult of Mithras. In: Nagel S, Quack JF, Witschel C (eds) Entangled worlds: Religious confluences between East and West in the Roman Empire. Mohr Siebeck, Tübingen, pp 384-412

Hochmuth M, Witteyer M (2008) Holocaustes et autres offrandes alimentaires dans le sanctuaire d'Isis et de Magna Mater à Mayence. In: Lepetz S, van Andringa W, Lepetz S (eds) Archéologie du sacrifice animal en Gaule romaine: Rituels et pratiques alimentaires. Mergoil, Montagnac, pp 119-123

Hochmuth M, Benecke N, Witteyer M (2005) Cocks and song birds for Isis Panthea and Mater Magna: the bird remains from a sanctuary in Mogontiacum/Mainz. In: Grupe G (ed) Feathers, grit and symbolism: Birds and humans in the ancient old and new worlds: proceedings of the 5. meeting of the ICAZ Bird Working Group in Munich (26.7. - 28.7.2004). Leidorf, Rahden Westfahlen, pp 319-327 
Huld-Zetsche I (1986) Mithras in Nida-Heddernheim. Archäologische Reihe, vol 6, Frankfurt am Main

Hüster Plogmann H (unpublished) Untersuchungen zu den Kleintierresten aus dem Heiligtum von Kempraten-Seewiese, Basel

Jans MM (2008) Microbial bioerosion of bone - a review. In: Wisshak M, Tapanila L (eds) Current developments in bioerosion, 1st edn. Springer, Berlin, Heidelberg, pp 397-413

Jans MM (2005) Histological characterisation of diagenetic alteration of archaeological bone. Geoarchaeological and Bioarchaeological Studies, vol 4, Amsterdam

Kern E (1991) Le mithraeum de Biesheim-Kunheim (Haut-Rhin). Revue Du Nord 73:59-65. https://doi.org/10.3406/rnord.1991. 4680

Koch P, Akeret Ö, Deschler-Erb S, Hüster Plogmann H, Pümpin C, Wick L (2018) Feasting in a sacred grove: a multidisciplinary study of the Gallo-Roman sanctuary of Kempraten, Switzerland. In: Livarda A, Madgwick R, Riera Mora S (eds) The Bioarchaeology of Ritual and Religion. Oxbow Books Limited, Havertown, pp 69-85

Lambrecht G, Mallol C (2020) Autofluorescence of experimentally heated bone: potential archaeological applications and relevance for estimating degree of burning. J Archaeol Sci Rep 31:102333. https://doi.org/10.1016/j.jasrep.2020.102333

Lisá L, Kočár P, Bajer A, Kočárová R, Syrová Z, Syrový J, Porubčanová M, Lisý P, Peška M, Ježková M (2020) The floor: a voice of human lifeways-a geo-ethnographical study of historical and recent floors at Dolní Němčí Mill, Czech Republic. Archaeol Anthropol Sci 12.https://doi.org/10.1007/s12520-020-01060-y

Liver A, Rageth J (2001) Neue Beiträge zur spätrömischen Kulthöhle von Zillis : die Grabungen von 1994/95. Zeitschrift Für Schweizerische Archäologie Und Kunstgeschichte 58:111-126. https:// doi.org/10.5169/SEALS-169617

Lo Russo S, Ackermann R, Flück H, Peter M (2018) The mithraeum at Kempraten: preliminary results from the mithraeum discovered at Kempraten (CH) in 2015/16. Acta Antiqua Academiae Scientiarum Hungaricae 58:199-215. https://doi.org/10.1556/068. 2018.58.1-4.12

Lo Russo S (2021a) Geoarchäologische Untersuchungen zu den Schichten der phase 1. In: Ebnöther C, Flückiger A, Peter M (2021) Zillis: Von der spätantiken Kulthöhle zum frühmittelalterlichen Bestattungsplatz. mit Beiträgen von Sabine Deschler-Erb, Sarah Lo Russo und Barbara Stopp, Chur, pp 41-53

Lo Russo S (2021b) Niveaulos oder abgehoben?: Geoarchäologische Untersuchungen zu Böden als Quellen zum Mithraskult in Kempraten (Rapperswil-Jona, SG). Masterarbeit 2018, Universität Basel. https://doi.org/10.5281/ZENODO.4467672

Martens M, Boe G de (eds) (2004) Roman Mithraism: the evidence of the small finds : [papers of the international conference...Tienen 7 - 8 november 2001]. Monografie, vol 4. Instituut voor het Archeologisch Patrimonium, Bruxelles

Mastrocinque A (2017) The mysteries of Mithras: a different account, $1^{\text {st }}$ ed. Orientalische Religionen in der Antike, v.24. Mohr Siebeck, Tübingen

Matthews W, Postgate JN, Charles M, Payne S, Dobney K (1994) The imprint of living in an early Mesopotamian city: questions and answers. In: Luff R (ed) Whither environmental archaeology? Oxbow Books, Oxford, pp 171-212

Matthews W, French C (2005) Domestic space at Saar: the microstratigraphic evidence. In: Killick RG, Moon J (eds) The Early Dilmun Settlement at Saa, London, New York, New York NY, pp 325-338

McCarty M, Egri M, Rustoiu A (2019) The archaeology of ancient cult: from foundation deposits to religion in Roman Mithraism. Journal of Roman Archaeology 32:279-312

McCarty M, Egri M (eds) (2020) The archaeology of Mithraism: new finds and approaches to Mithras-worship. Babesch Supplement Series, vol 39, Leuven
Mentzer SM, Romano DG, Voyatzis ME (2015) Micromorphological contributions to the study of ritual behavior at the ash altar to Zeus on Mt. Lykaion, Greece. Archaeological and Anthropological Sciences:1017-1043. https://doi.org/10.1007/s12520-014-0219-y

Mentzer SM, Quade J (2012) Compositional and isotopic analytical methods in archaeological micromorphology. Geoarchaeology 28:87-97. https://doi.org/10.1002/gea.21425

Mentzer SM (2018) Micromorphological analyses of anthropogenic materials and insights into tell formation processes at Aşıklı Höyük, 2008-2012 field seasons. In: Özbaşaran M, Duru G, Stiner MC (eds) The early settlement at Aşıklı Höyük: Essays in honor of Ufuk Esin. Ege Yayınları, İstanbul, pp 105-128

Milek KB (2012) Floor formation processes and the interpretation of site activity areas: an ethnoarchaeological study of turf buildings at Thverá, northeast Iceland. J Anthropol Archaeol 31:119-137. https://doi.org/10.1016/j.jaa.2011.11.001

Milek KB, Roberts HM (2013) Integrated geoarchaeological methods for the determination of site activity areas: a study of a Viking Age house in Reykjavik, Iceland. J Archaeol Sci 40:1845-1865. https://doi.org/10.1016/j.jas.2012.10.031

Nagel S, Quack JF, Witschel C (eds) (2017) Entangled worlds: religious confluences between East and West in the Roman Empire. Orientalische Religionen in der Antike, vol 22. Mohr Siebeck, Tübingen

Olive C (2008) Honorer Mithra en mangeant: le menu des mithriastes d'Orbe et de Martigny. In: Lepetz S, van Andringa W, Lepetz S (eds) Archéologie du sacrifice animal en Gaule romaine: Rituels et pratiques alimentaires. Mergoil, Montagnac, pp 267-275

Pérez L, Sanchis A, Hernández CM, Galván B, Sala R, Mallol C (2017) Hearths and bones: an experimental study to explore temporality in archaeological contexts based on taphonomical changes in burnt bones. J Archaeol Sci Rep 11:287-309. https://doi.org/10. 1016/j.jasrep.2016.11.036

Peters (2021) OssoBook Datenbank Software. https://www.archa eobiocenter.uni-muenchen.de/forschung/datenbank/index.html. Accessed 20 December 2021

Pétry F (1976) Ciconscription D'alsace Gallia 34:379-411

Rageth J (1994) Ein spätrömischer Kultplatz in einer Höhle bei Zillis GR. Zeitschrift Für Schweizerische Archäologie Und Kunstgeschichte 51:141-172. https://doi.org/10.5169/SEALS-169415

Reddé M (ed) (2011) Oedenburg, Volume 2: L'agglomération civile et les sanctuaires. Part 2: Matériel et études. Monographien des Römisch-Germanischen Zentralmuseums, 79/2, Mainz

Rentzel P, Nicosia C, Gebhardt A, Brönnimann D, Pümpin C, IsmailMeyer K (2017) Trampling, poaching and the effect of traffic. In: Nicosia C, Stoops G (eds) Archaeological soil and sediment micromorphology. Wiley Blackwell, Hoboken, pp 281-297

Rentzel P (2011) Kapitel 13 - Anhang: Spuren der Nutzung im Mithraeum von Biesheim: Mikromorphologische Untersuchungen. In: Reddé M (ed) Oedenburg, Volume 2: L'agglomération civile et les sanctuaires. Part 2: Matériel et études, Mainz, pp 248-255

Richmond IA, Gillam JP (1951) The Temple of Mithras at Carrawburgh. The Society of Antiquaries, Newcastle, With a Contribution by Eric Birley

Romano DG, Voyatzis ME (2014) Mt. Lykaion excavation and survey project, part 1: the upper sanctuary. Hesperia: The Journal of the American School of Classical Studies at Athens 83:569-652. https://doi.org/10.2972/hesperia.83.4.0569

Scheid J (2007) Sacrifices for Gods and Ancestors. In: Rüpke J (ed) A companion to Roman religion. Blackwell, Malden, Mass.

Schucany C, Schwarz P-A, Girardclos O, Lehnert U, Neukomm C, Petit C, Popovitch L, Schlumbaum A, Wick L, Wullschleger M, Flück M, Rentzel P (2011) Der Gallorömische Tempelbezirk. In: Reddé M (ed) Oedenburg, Volume 2: L'agglomération civile et les sanctuaires. Part 2: Matériel et études, II, Mainz, pp 58-286 
Snoeck C, Lee-Thorp JA, Schulting RJ (2014) From bone to ash: compositional and structural changes in burned modern and archaeological bone. Palaeogeogr Palaeoclimatol Palaeoecol 416:55-68. https://doi. org/10.1016/j.palaeo.2014.08.002

Squires KE, Thompson TJ, Islam M, Chamberlain A (2011) The application of histomorphometry and Fourier Transform Infrared Spectroscopy to the analysis of early Anglo-Saxon burned bone. J Archaeol Sci 38:2399-2409. https://doi.org/10.1016/j. jas.2011.04.025

Stiner MC, Kuhn SL, Weiner S, Bar-Yosef O (1995) Differential burning, recrystallization, and fragmentation of archaeological bone. $\mathrm{J}$ Archaeol Sci 22:223-237. https://doi.org/10.1006/jasc.1995.0024

Stoops G (2003) Guidelines for analysis and description of soil and regolith thin sections. Soil Science Society of America, Madison
Symes SA, L'Abbé EN, Pokines JT, Yuzwa T, Messer D, Stromquist A, Keough N (2013) Thermal alteration of bone. In: Pokines JT, Symes SA (eds) Manual of forensic taphonomy. CRC Press, Taylor \& Francis Group, Boca Raton, pp 367-402

Turner-Walker G, Jans MM (2008) Reconstructing taphonomic histories using histological analysis. Palaeogeogr Palaeoclimatol Palaeoecol 266:227-235

Wahl J (1981) Beobachtungen zur Verbrennung menschlicher Leichname: Über die Vergleichbarkeit moderner Kremationen mit prähistorischen Leichenbränden. Archäologisches Korrespondenzblatt 11:271-279

Publisher's note Springer Nature remains neutral with regard to jurisdictional claims in published maps and institutional affiliations. 